Article

\title{
The Provenance of Marbles and Alabasters Used in the Monuments of Hierapolis in Phrygia (Turkey): New Information from a Systematic Review and Integration of Archaeological and Archaeometric Data
}

\section{Giuseppe Scardozzi}

Institute for Archaeological and Monumental Heritage, National Research Council of Italy, Monteroni Road, 73100 Lecce, Italy; g.scardozzi@ibam.cnr.it

Received: 31 December 2018; Accepted: 31 January 2019; Published: 6 February 2019

\begin{abstract}
Determining the provenance of the stones used for ancient architectures is very important in order to reconstruct many social and economic questions linked to the life of a city. This paper integrates previous and new archaeometric data about marble and alabaster quarries in south-western Phrygia (Lykos valley), and offers a review of some results of the research activities carried out between the years 2013-2018 and aimed to reconstruct the building stone procurement strategies adopted in the city of Hierapolis in Phrygia across a broad chronological time span from the Hellenistic age to the Byzantine period. The research activities based on a multidisciplinary approach, integrating the archaeological and art-historian study of the monuments, the topographical investigation of the quarries, and the archaeometric characterisation both of extraction sites and marbles and alabasters used in the building sites of the urban area and in the necropolises.
\end{abstract}

Keywords: marble; alabaster; quarry; building site; archaeology; archaeometry; Asia Minor; Roman Imperial period

\section{Introduction, Study Area, and Research Aim}

Numerous studies in the last few years have concentrated on the role of marble architecture in Rome and on the importation of high-value materials to the center of power during the Imperial age. In contrast, the main focus of the research carried out from 2013 in Hierapolis of Phrygia (south-western Turkey) has been the reconstruction of the building stone procurement strategies adopted by one of the many provincial cities which formed the basic fabric of the Roman Empire. Indeed, a key concern of the research has been the municipal dimension of monumental building, which was strongly conditioned by intrinsically local factors, such as the natural resources available in the territory, building traditions, social organization, etc.

This study belongs to a line of research into ancient building sites, which, by means of a multidisciplinary approach, not only studies the strictly art-historical aspects of the monuments, but also seeks to reconstruct the economic and social dynamics associated with the construction of great public complexes. The reconstruction of the building stone procurement strategies adopted in Hierapolis concerns a broad chronological time span from the Hellenistic epoch to the Byzantine period. Extensive knowledge of the territory surrounding the city and detailed research into its monuments provided the basis for a painstaking historical reconstruction. Indeed, Hierapolis is one of the best known and most extensively studied urban settlements in Asia Minor thanks to sixty years of research by the Italian Archaeological Mission [1-12]. Hierapolis was founded in the 3rd century BC by Greek-Macedonian colonists of the Seleucid Reign and was an important city of the Roman and Byzantine Empires, when it was famous for the presence respectively of an oracular sanctuary of 
Apollo and the Ploutonion (one of the access to the Hades identified in antiquity) and the tomb of the Apostle Philip (one of the most relevant pilgrimage destinations in Asia Minor during the Medieval age). The urban area of Hierapolis, abandoned in the 13th-14th centuries AD during the wars between the Byzantines and Seljuk Turks for control of the Anatolian peninsula, stretches over a travertine shelf looking out onto the broad and fertile valley of the Çürüksu River, corresponding with the ancient Lykos River, one of the tributaries of the Maeander River (today Büyük Menderes River). Hierapolis and its territory were on the northern side of the Lykos valley, corresponding with the modern Denizli basin, and at a short distance from the city, in the same valley, were two other important centers with their territories, Tripolis on the Maeander and Laodikeia on the Lykos (located respectively at about 20 and $10 \mathrm{~km}$ to the north-west and south-east of Hierapolis: Figure 1), where recent and extensive investigations performed by Turkish archaeologists have largely increased the knowledge of their history and monuments [13-19].

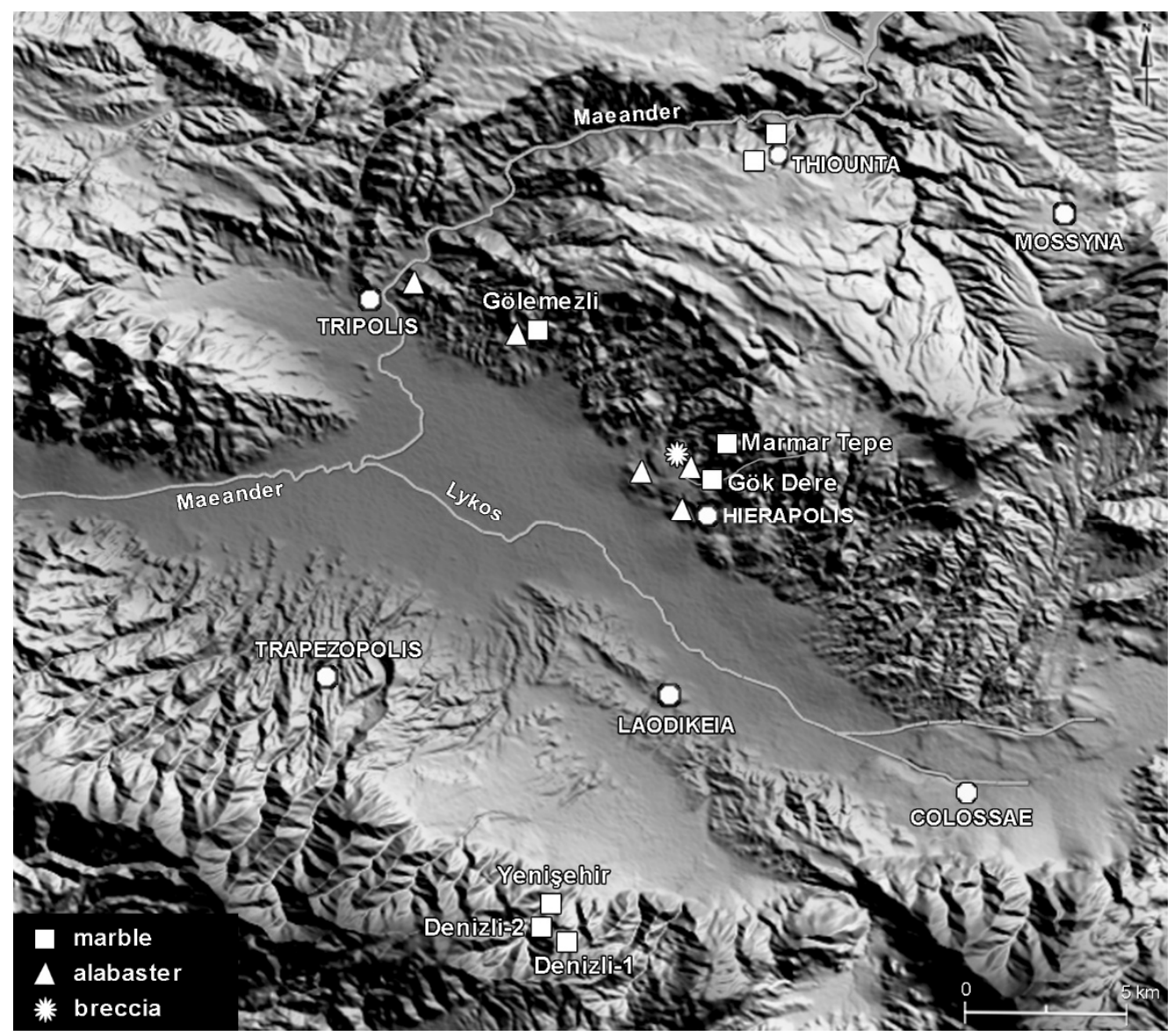

Figure 1. Digital Elevation Model of the Denizli basin (processed from data by Shuttle Radar Topography Mission), with location of the ancient marble, alabaster and breccia quarries.

The building materials used in the monuments of Hierapolis are mainly marble (both white, white veined, and grey), travertine, calcite alabaster, and polychromatic breccia. These stones were widely available in the territory immediately surrounding the city, where they were extensively quarried in antiquity. Indeed, the Lykos valley constituted an important extractive district in southwestern Phrygia, characterized by numerous quarries along the northern and southern sides of the Denizli basin, where the peculiar geological characteristics of the area [20-24] allowed for the presence of a large variety of building stones (Figure 2). 


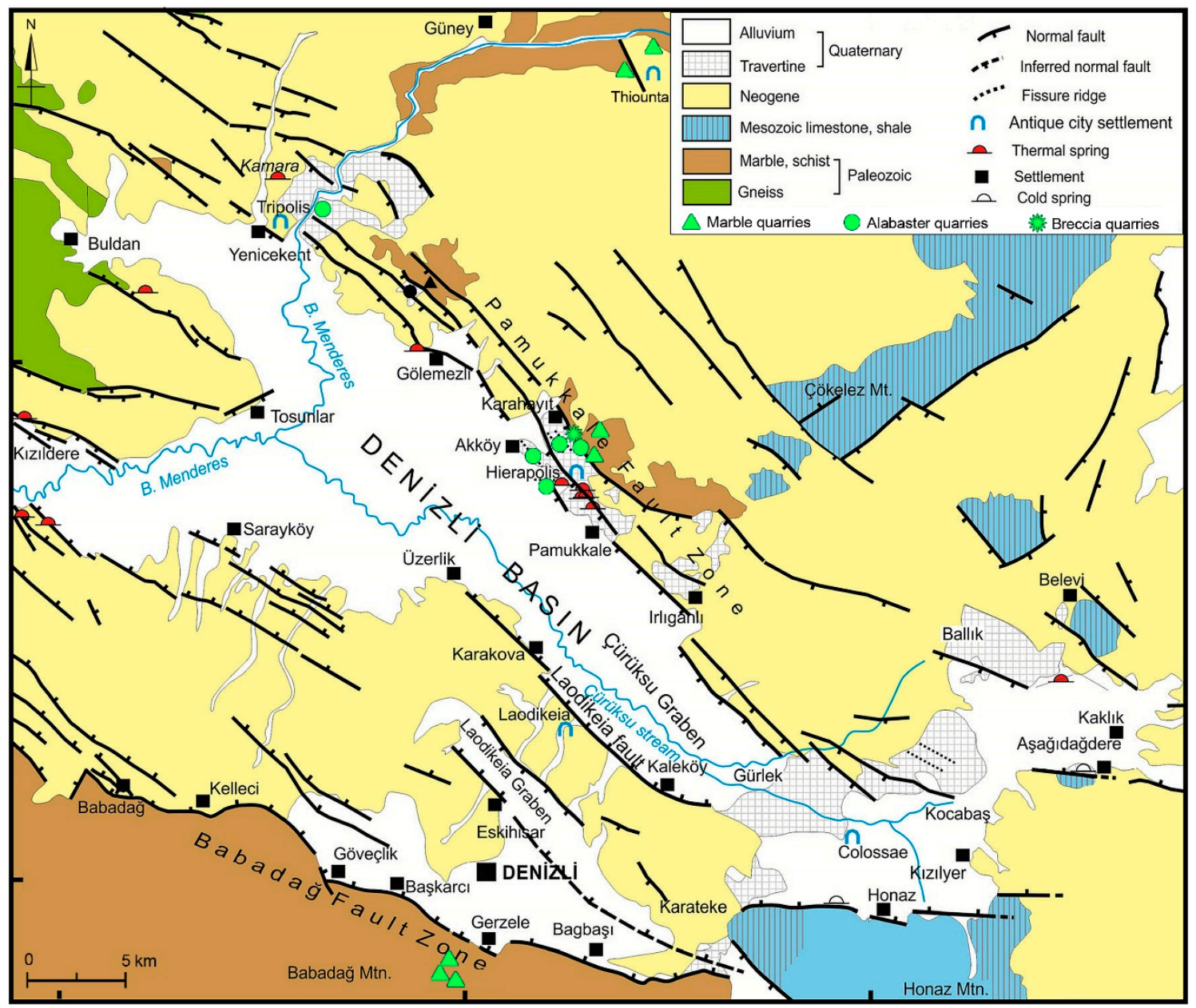

Figure 2. Simplified geological map of the Denizli basin, with location of the ancient marble, alabaster and breccia quarries. Modified after [23] (Figure 2).

This paper is especially focused on reconstruction of the marble and alabaster procurement strategies adopted in Hierapolis during the period from the Augustan age to the Severan epoch, which corresponds to building phases that saw extensive use of these stones. Indeed, after $240 \mathrm{AD}$, the system of municipal patronage fell into crisis and significant new construction projects would not be seen again until the early-Byzantine age, when Hierapolis became an important centre of Christianity. However, during the last period, the building sites of the cities were characterized by a systematic reuse of stone materials by previous monuments of the urban area and necropolises, without a resumption of the large extraction activities in the quarries such as during the Hellenistic age and the early centuries of the Roman Imperial period.

In particular, this study offers a review and discussion on the results of systematic archaeological and archaeometric investigations performed in the last years in the marble and alabaster quarries of the territory of Hierapolis and in the public monuments of the city. These data [25] (pp. 1-668) are integrated with data collected in the neighbouring territories of Laodikeia and Tripolis, in order to provide a more complete framework of the extraction sites in the Lykos valley. About marbles, the integration and reorganization of the available archaeometric data allowed to build a rich database of the quarries in the Lykos valley. Moreover, data from the quarries were cross-referenced with data from the building sites and vice versa. Thus, the systematic study and detailed archaeometric characterization of the quarries and the architectural elements from monuments enabled precise determination of the provenance of the marbles used in the building sites of Hierapolis, while extensive knowledge of the building phases of the monumental complexes made 
it possible to diachronically determine the contribution of the various local quarrying districts and imported materials. About alabasters, the research is still in progress and, despite the archaeometric characterization of the quarries being sufficiently performed, further investigations on the architectural materials from the cities of the Lykos valley will be necessary. In this case, the results of recent investigations on the provenance of alabasters used in Hierapolis and Tripolis are reviewed using a more complete dataset of the archaeometric characterization of the quarries of Lykos valley.

\section{Materials and Methods}

About the marble and alabaster quarries, systematic archaeological and topographical surveys have reconstructed the ancient landscape of the extraction sites in the territory of Hierapolis and in the remaining areas of the Lykos valley. The extension and characteristics of the quarrying sectors, the techniques for extraction, the quantities of material extracted, the areas where the detritus was dumped, and the presence of activities linked to the roughing out of specific artefacts have been determined [26,27]. The quarries and the ancient road network were georeferenced on large-scale topographical maps and high-resolution satellite ortho-images, identifying the slipways and establishing the routes used for transporting the material to the city. Multitemporal satellite images were processed for the documentation of the quarries and their surrounding areas and for the identification of quarrying sectors that had been destroyed (due to the resumption of extraction activities in recent years) or filled in with detritus during last decades. Even aerial filming of the quarries (faces and trenches) by means of a small remote-controlled drone was performed [28]. This archaeological study of the quarries was also strictly integrated with geological surveys of the same area, aimed at the investigation of the peculiar geomorphological, hydrogeological, and tectonic characteristics of the territory, which determined the presence of different varieties of stones in the Denizli basin [29].

At the same time, some of the main Roman Imperial and Byzantine monuments of the urban area of Hierapolis (such as the North Agora, the Nymphaeum of Tritons, the Sanctuary of Apollo, the Civil or Central Agora, the Ploutonion with the nearby Stoa of the Springs, the Marble Stoa, the Theatre, the so-called Bouleuterion, the Gymnasium, the St. Philip Church, and the early-Byzantine city walls) and surrounding necropolises, which were characterized by extensive use of architectural elements especially in marble and in some cases also in alabaster, were systematically studied [25] (pp. 231-419, 473-509). The investigations were conducted in accordance with a multidisciplinary approach that considered the floor plans, elevations, and decorative schemes, as well as the design and construction processes, in order to reconstruct the organization of the building sites and the division of the work among various craftsmen [30]. In addition, special attention was paid to the ancient stone working and restoration techniques, particularly significant in a seismic context such as Hierapolis), as well as the presence of demolition sites and the practice of reusing construction materials [31-33].

\section{Analytical Methods}

In order to reconstruct the building stone procurement strategies adopted in Hierapolis between the Imperial and Byzantine periods, the archaeometric characterisation of quarries and archaeological materials used in the building sites were carried out. The research was particularly focused on the white marble, which constitutes the precious stone most used in Hierapolis and whose provenance is more difficult to define. Therefore, hundreds of samples of white marble collected from the quarry faces of the Lykos valley (about 180 samples, integrated to the samples available in literature especially for local quarries [34-37]) and archaeological materials (about 270 samples from the urban area and 70 from the necropolises) were accurately georeferenced and analysed [38,39]. For the archaeometric characterization of these marbles, three different types of investigation were integrated: (i) minero-petrographic and XRD analyses, conducted in CNR-IBAM's Laboratory of Optical and Electronic Microscopy in Lecce; (ii) oxygen and carbon stable isotope analyses, carried out in CNR-IGAG's Laboratory of Mass Spectrometry in Rome; (iii) cathodoluminescence analyses, 
conducted in the laboratories of the UEA-ICAC (Unitat d'Estudis Arqueométrics of the Institut Català d'Arqueologia Clàssica) in Tarragona.

Lastly, about the calcite alabasters (the so called listato, fiorito, and ghiaccione types), 55 samples from the quarries of the territory of Hierapolis were characterized by means of X-Ray Diffractometry, oxygen, and carbon stable isotope analyses, carried out in the already mentioned CNR-IGAG's Laboratory of Mass Spectrometry in Rome [40]. These data were integrated with carbon and oxygen stable isotope compositions of samples of calcite alabaster from the ancient quarries of the same area, already available in the geological literature [22,41,42], where it is called banded travertine. Moreover, 15 samples were collected from archaeological materials in alabaster discovered in the urban area of Hierapolis with the aim of testing the possibility of archaeometrically determining the provenance of the stone through XRD and isotopic analyses [43]. These data have been integrated by the recent publication of the geological and archaeometric data about the alabaster quarries close to Tripolis [44-46] and the village of Gölemezli [47] (it is uncertain if the last site belonged to the territory of Tripolis itself or Hierapolis. Thus, the enriched dataset of the quarries allows us to review the results of the attribution of provenance of archaeological samples from Hierapolis and Tripolis.

About the instrumentation used for archaeometric characterization, XRD analyses, aimed at differentiating between the presence of calcite and/or dolomite in the marble samples and the presence of calcite and/or aragonite in the alabaster samples, were performed using a Philips PW 1840 diffractometer under the following scan conditions: radiation $\mathrm{CuKa} / \mathrm{Ni}, 40 \mathrm{KV} \& 20 \mathrm{~mA}$. Semi-quantitative mineral composition was determined with XPowder12 freeware software.

Thin sections of the samples were prepared for the mineralogical-petrographic investigation under a polarizing microscope (Nikon Mod. Eclipse LV 100 POL). The aim of this investigation was to evaluate the presence of accessory minerals and to establish some microstructural features (such as MGS, crystal boundary shapes, texture, and fabric types, etc.) that are characteristic of each variety of investigated stone.

Oxygen and carbon isotopes of marbles and alabasters were determined on calcium carbonate samples by isotope ratio mass spectrometry. A Finnigan MAT Kiel II automatic preparation device was used for phosphoric acid digestion at $72{ }^{\circ} \mathrm{C}$ and $\mathrm{CO}_{2}$ purification; a Finnigan MAT 252 mass spectrometer measured the carbon and oxygen isotope ratios of carbon dioxide expressed in the usual delta notation, which represents the relative deviation in parts per thousand of the heavy isotope/light isotope ratio of the samples from that of a reference standard. The international standard used is PDB for both oxygen and carbon isotopes.

Lastly, cathodoluminescence microscopy was also performed on the thin sections of marble samples, which were polished for this purpose. Cathodoluminescence was carried out with CL8200 Mk5-1 cold equipment coupled with a Nikon Eclipse 50iPOL OM. The electron energy was $15-20 \mathrm{kV}$, and the beam current was operated at 250-300 mA. The observed luminescent colours, intensity, and distribution in each sample were recorded with an automatic digital Nikon Coolpix5400 camera. The Cathodoluminescence images taken were automatically controlled ( $29 \mathrm{~mm}$ focal length, $\mathrm{f} / 4.6$ aperture, $1 \mathrm{~s}$ exposure, ISO-200) to obtain comparative images of their cathodoluminescence intensity (brightness).

\section{Results and Discussion}

\subsection{An Overview on the Marble Quarries in the Lykos Valley and a Review of their Archaeometric Characterization}

The most important result of the archaeological and geological investigations in the territory of Hierapolis was the identification of four main extraction areas [26], where four varieties of marble were extracted: two were quarried very close to the city (Hierapolis-Gök Dere and Marmar Tepe), and other two further away (Thiounta and Gölemezli) (Figures 1 and 2). The archaeometric characterization of the quarry faces (Tables 1 and A1 in Appendix A; Figure 3A-D; Figures 4 and 5), thanks to the collection and analyses (mineralogical-petrographic, carbon and oxygen stable isotopes, and cathodoluminescence) 
of 135 samples and the integration of these data with those already available in the literature [35,36], allowed for the discrimination of both these marbles among them and from the other white marbles extracted in southwestern Anatolia in antiquity [38].

Table 1. Summary of the mineralogical-petrographical and cathodoluminescence features of the marble quarries of Lykos valley, based on data from [35] (Tables 2.17, 2.18, 2.19), [36] (Table 1, Figure 6), [37] (Figures 4-5), [38] (Table 4).

\begin{tabular}{|c|c|c|c|c|c|c|c|c|c|c|c|c|c|c|c|}
\hline Quarries & $\mathbf{Q}$ & $\mathrm{Km}$ & Ap & Gr & Pl & OP & $\mathrm{CC}$ & Dol & Texture & Fabric & $\begin{array}{c}\text { Calcite } \\
\text { Crystal } \\
\text { Boundaries }\end{array}$ & MGS & $\begin{array}{c}\mathrm{CL} \\
\text { Intensity }\end{array}$ & $\begin{array}{c}\text { CL } \\
\text { Texture }\end{array}$ & Literature \\
\hline $\begin{array}{l}\text { Hierapolis- } \\
\text { Gök Dere }\end{array}$ & + & ++ & \pm & + & \pm & + & main & \pm & $\begin{array}{l}\text { Isotropic, } \\
\text { anisotropic, } \\
\mathrm{HO} / \mathrm{HE}\end{array}$ & $\begin{array}{c}\text { Mosaic } \\
\text { W-lineated } \\
\text { Triple } \\
\text { junctions }\end{array}$ & $\begin{array}{l}\text { Straight } \pm \\
\text { curved } \pm \\
\text { embayed }\end{array}$ & $0.20-3.50$ & $\mathrm{~L} / \mathrm{M} / \mathrm{H}$ & $\begin{array}{c}\text { Hom, } \\
\text { Het, } \\
\text { patchy }\end{array}$ & {$[35,36,38]$} \\
\hline $\begin{array}{l}\text { Marmar } \\
\text { Tepe }\end{array}$ & ++ & ++ & + & ++ & + & + & only & \pm & $\begin{array}{c}\text { Isotropic, } \\
\text { W-anisotropic, } \\
\text { HO/HE }\end{array}$ & $\begin{array}{c}\text { Granoblastic } \\
\text { (interlocked), } \\
\text { W-lineated } \\
\text { Triple } \\
\text { junctions }\end{array}$ & $\begin{array}{c}\text { Curved } \pm \\
\text { straight } \pm \\
\text { sutured }\end{array}$ & $2.00-4.50$ & $\mathrm{LL} / \mathrm{L} / \mathrm{M}$ & $\begin{array}{l}\text { Hom, } \\
\text { Het, } \\
\text { patchy }\end{array}$ & [38] \\
\hline Thiounta & \pm & & & ++ & & & only & \pm & $\begin{array}{l}\text { Isotropic } \\
\mathrm{HO} / \mathrm{W}-\mathrm{HE}\end{array}$ & $\begin{array}{l}\text { Granoblastic, } \\
\text { Sg } \\
\text { (interlocked) }\end{array}$ & $\begin{array}{c}\text { Curved } \pm \\
\text { straight } \pm \\
\text { embayed } \pm \\
\text { sutured }\end{array}$ & $0.80-5.00$ & $\mathrm{LL} / \mathrm{L}$ & Hom & {$[35,38]$} \\
\hline Gölemezli & \pm & & & ++ & & \pm & only & \pm & $\begin{array}{l}\text { Isotropic, } \\
\mathrm{HO} / \mathrm{W}-\mathrm{HE}\end{array}$ & $\begin{array}{l}\text { Granoblastic } \\
\text { (interlocked) }\end{array}$ & $\begin{array}{l}\text { Straight } \pm \\
\text { curved } \pm \\
\text { sutured }\end{array}$ & $3.20-5.20$ & $\mathrm{LL} / \mathrm{M}$ & $\begin{array}{l}\text { Hom, } \\
\text { Het, } \\
\text { patchy }\end{array}$ & [38] \\
\hline Denizli-1 & + & \pm & \pm & + & + & \pm & only & \pm & $\begin{array}{l}\text { Isotropic, } \\
\mathrm{HO} / \mathrm{HE}\end{array}$ & $\begin{array}{c}\text { Mosaic, } \\
\text { (interlocked) }\end{array}$ & $\begin{array}{l}\text { Curved, } \\
\text { straight, } \\
\text { embayed }\end{array}$ & $0.90-4.00$ & $\begin{array}{l}\mathrm{L} / \mathrm{LL} / \\
\mathrm{M} / \mathrm{H}\end{array}$ & $\begin{array}{l}\text { Hom, } \\
\text { Het, Bo, } \\
\text { zoned, } \\
\text { relict }\end{array}$ & {$[35,36,38]$} \\
\hline Denizli-2 & + & \pm & \pm & + & + & \pm & only & \pm & $\begin{array}{l}\text { Isotropic, } \\
\mathrm{HO} / \mathrm{HE}\end{array}$ & $\begin{array}{l}\text { Mosaic, } \\
\text { polygonal }\end{array}$ & $\begin{array}{l}\text { Curved, } \\
\text { straight, } \\
\text { embayed }\end{array}$ & $0.26-2.40$ & LL & Hom & {$[35,36,38]$} \\
\hline Denizli-3 & n.a. & n.a. & n.a. & n.a. & n.a. & n.a. & n.a. & n.a. & n.a. & n.a. & n.a. & $2.40-3.50$ & n.a. & n.a. & [35] \\
\hline Yenişehir & \pm & & & & + & \pm & main & \pm & $\begin{array}{l}\text { Isotropic, } \\
\mathrm{HO} / \mathrm{HE}\end{array}$ & $\begin{array}{c}\text { Mosaic, } \\
\text { polygonal }\end{array}$ & n.a. & $0.18-2.22$ & n.a. & n.a. & [37] \\
\hline $\begin{array}{l}Q=q u \\
\text { and } D \\
\text { suture } \\
\text { intensi } \\
\text { CL tex }\end{array}$ & $\begin{array}{l}\text { lartz, } \\
\text { ol = } \\
\text { d gra } \\
\text { ity, N }\end{array}$ & $\begin{array}{l}\mathrm{Km} \\
\text { dolor } \\
\text { ain bc } \\
\mathrm{A}=\mathrm{m}\end{array}$ & $\begin{array}{l}=p \\
\text { mite } \\
\text { oun } \\
\text { nedi }\end{array}$ & 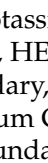 & $=$ he & ter & $\begin{array}{l}\text { Ap = } \\
\text { blasti } \\
\text { akly, N } \\
\text { ity, L }\end{array}$ & pati & $\begin{array}{l}\text { ite, } \mathrm{Gr}=\text { gra } \\
\text { ure, } \mathrm{HO}=\mathrm{h} \\
=\text { maximum } \\
\mathrm{CL} \text { intensit }\end{array}$ & $\begin{array}{l}\text { phite, } \mathrm{Pl}=\mathrm{f} \\
\text { omeoblasti } \\
\text { grain size } \\
\text { ty, Hom }=\mathrm{h} \\
\text { a not availa }\end{array}$ & $\begin{array}{l}\text { agioclase, } \\
\text { texture, } \\
\mathrm{nm}), \mathrm{CL}= \\
\text { mogenec }\end{array}$ & $\begin{array}{l}\mathrm{P}=\mathrm{Op} \\
=\text { small } \\
\text { athodol } \\
\text { CL tex }\end{array}$ & $\begin{array}{l}\text { ue min } \\
\text { ubgrair } \\
\text { minesce } \\
\text { Ire, Het }\end{array}$ & $\begin{array}{l}\text { als, CC } \\
\text { enclose } \\
\text { ce, } \mathrm{H}= \\
\text { hetero }\end{array}$ & $\begin{array}{l}\text { calcite } \\
\text { at the } \\
\text { gh CL } \\
\text { neous }\end{array}$ \\
\hline
\end{tabular}

The Hierapolis-Gök Dere and Marmar Tepe marbles were quarried a short distance from each other. Indeed, the Hierapolis-Gök Dere marble was quarried about $1.5 \mathrm{~km}$ north of the city, along the valley of the seasonal stream named Gök Dere and about $700 \mathrm{~m}$ further north-west, at the top of the hill that lies immediately to the north of the same valley. Overall, 7 quarries, partially destroyed by the modern resumption of extraction activities, were identified and it can be calculated that at least $9000 \mathrm{~m}^{3}$ of marble have been extracted from this area. The extraction was conducted on successive benches (stepped levels) on the hillsides and the quarry faces reach $40 \mathrm{~m}$ in length and 10-12 $\mathrm{m}$ in height. The Hierapolis-Gök Dere marble is generally white, but is often spotted in tones from yellowish to grey (rarely black), with grey veins and, sometimes, rusty orange or reddish alabaster patches. The grain is generally irregular, varying from medium to large, while the consistency is prevailingly uneven, with some compact parts and others friable. The MGS of most samples measures between 0.95 and $2 \mathrm{~mm}$ for the white (and white striated) variety; the less attested grey and black varieties generally have MGS respectively 0.55 and $3.20 \mathrm{~mm}$ and between 0.80 and $1.80 \mathrm{~mm}$. Cathodoluminescence of this marble is both homogeneous and heterogeneous with low to medium-high intensity, while isotopes are between -0.74 and $3.69 \%$ for carbon and between -10.05 and $-5.73 \%$ for oxygen. 


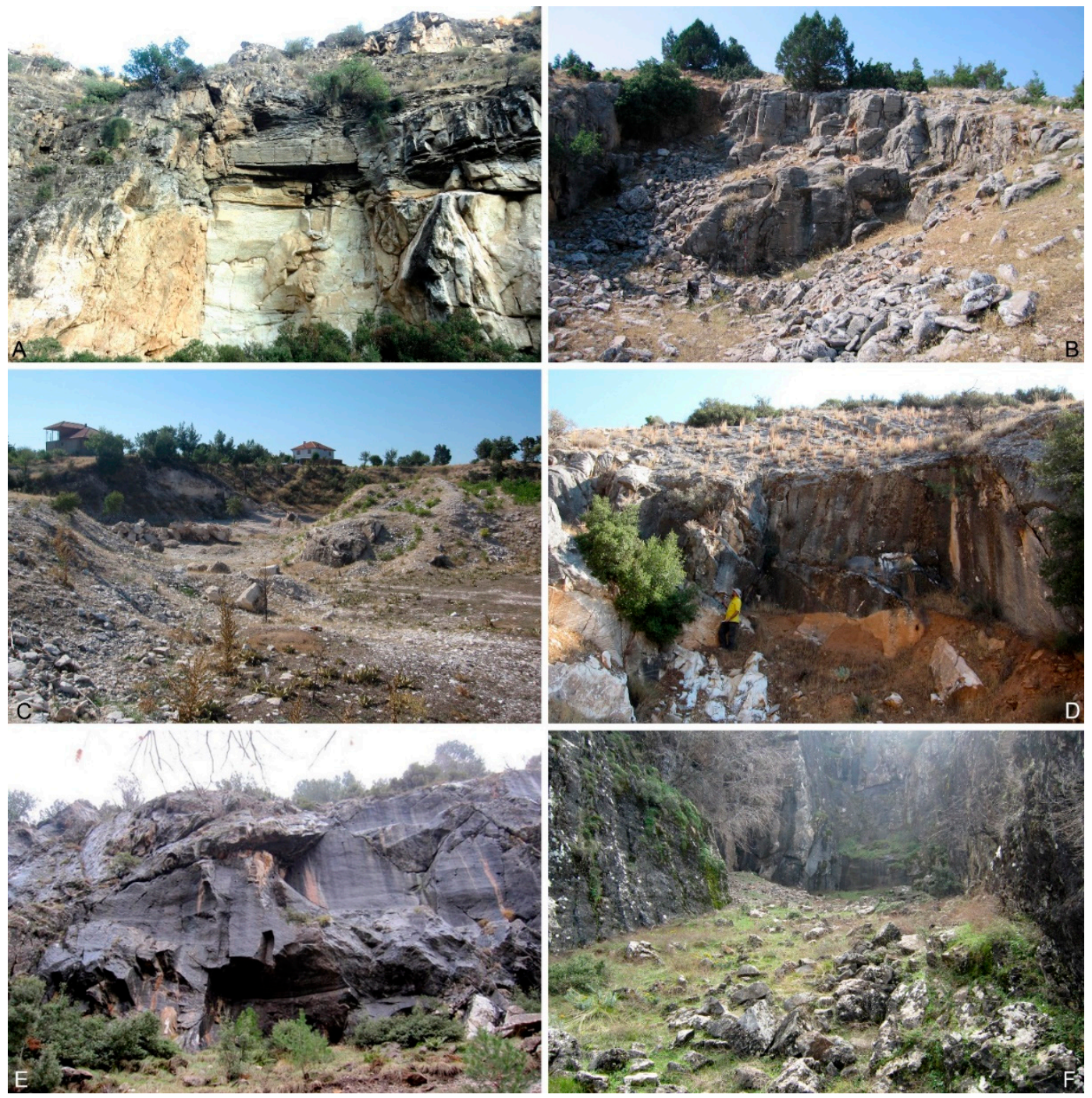

Figure 3. Photographs of marble quarries of Lykos valley: (A) Hierapolis-Gök Dere; (B) Marmar Tepe; (C) Thiounta; (D) Gölemezli; (E) Denizli-2; (F) Yenişehir.

The largest extraction area in the territory of Hierapolis is on the mountain named Marmar Tepe, about $2 \mathrm{~km}$ north of the city. Overall, 47 quarries were identified and it can be calculated that at least $21,000 \mathrm{~m}^{3}$ of marble have been extracted from this area. The quarries are in the southern slope of the mountain, where many pits in the bedrock of variable dimensions, up to $6 \mathrm{~m}$ deep, $20 \mathrm{~m}$ wide, and $50 \mathrm{~m}$ long, are still preserved. Extraction took place on a series of benches (steps), often exploiting the natural cracks in the rock. The Marmar Tepe marble is very heterogeneous and its macroscopic aspect is highly variable, from compact to poorly cohesive. It is white (often with greyish veins) to greyish in colour and has a heterogeneous medium-large grain size with a measured MGS of most samples between 2.10 and $3.20 \mathrm{~mm}$ for both the white and the grey varieties. Isotopes range mostly between -6.15 and $-1.78 \%$ for the oxygen and between 0.09 and $2.54 \%$ for the carbon. Moreover, the cathodoluminescence of the Marmar Tepe white marble shows a distribution mostly homogeneous, generally with very low and low intensity, sometimes medium. Instead, in the Marmar Tepe grey marble, cathodoluminescence is generally less uniform, with homogeneous and heterogeneous texture, and it is possible to observe samples with medium, even high, intensity and other ones with red or dark red luminescence of low or very low intensity. 


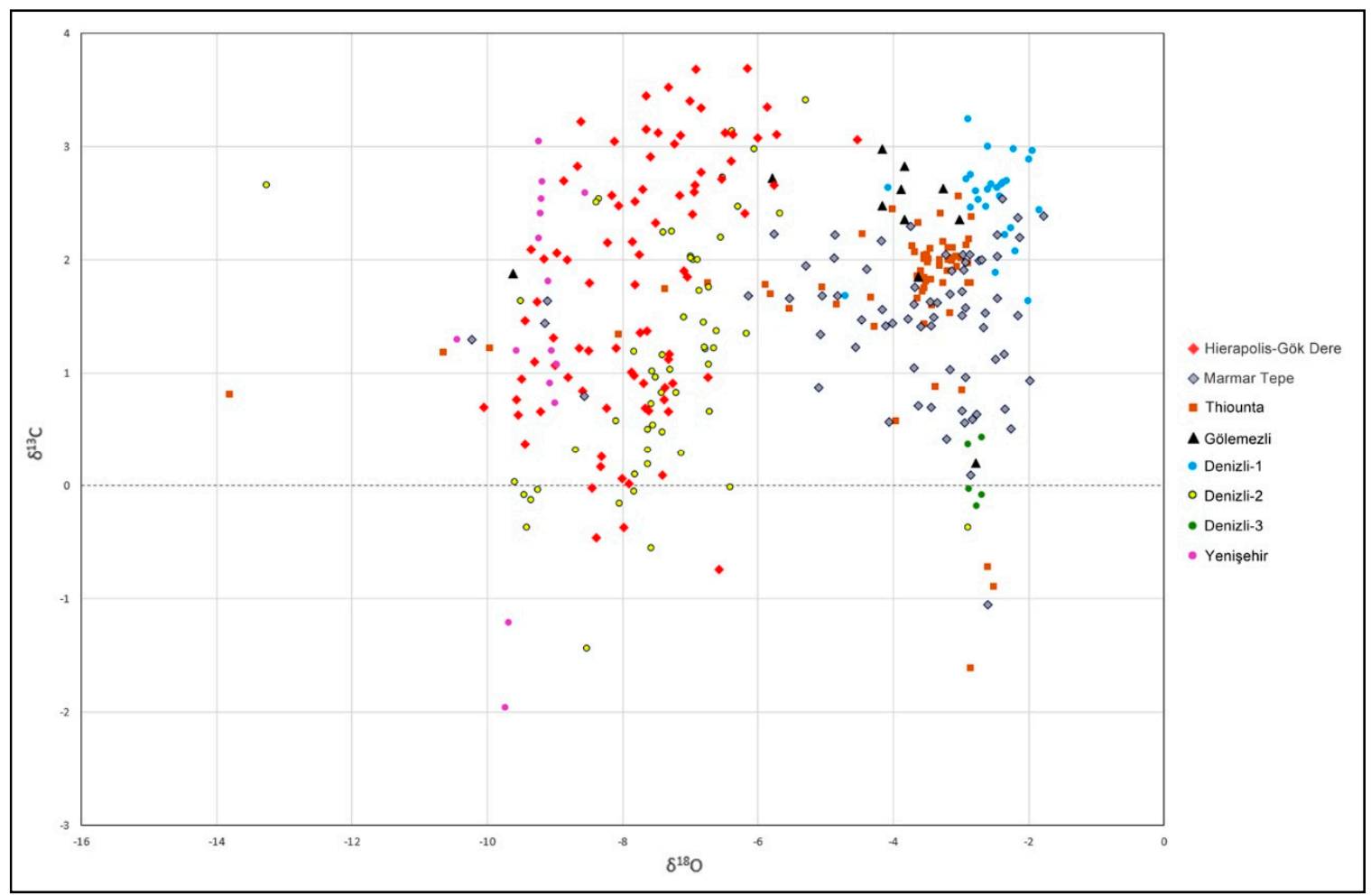

Figure 4. C-O stable isotopes diagram of the marble quarries of Lykos valley based on data from [35] (Tables 2.17, 2.18, 2.19), [36] (Table 7), [37] (Table 2), [38] (Table 3). Isotopes are expressed versus the V-PDB international standard.

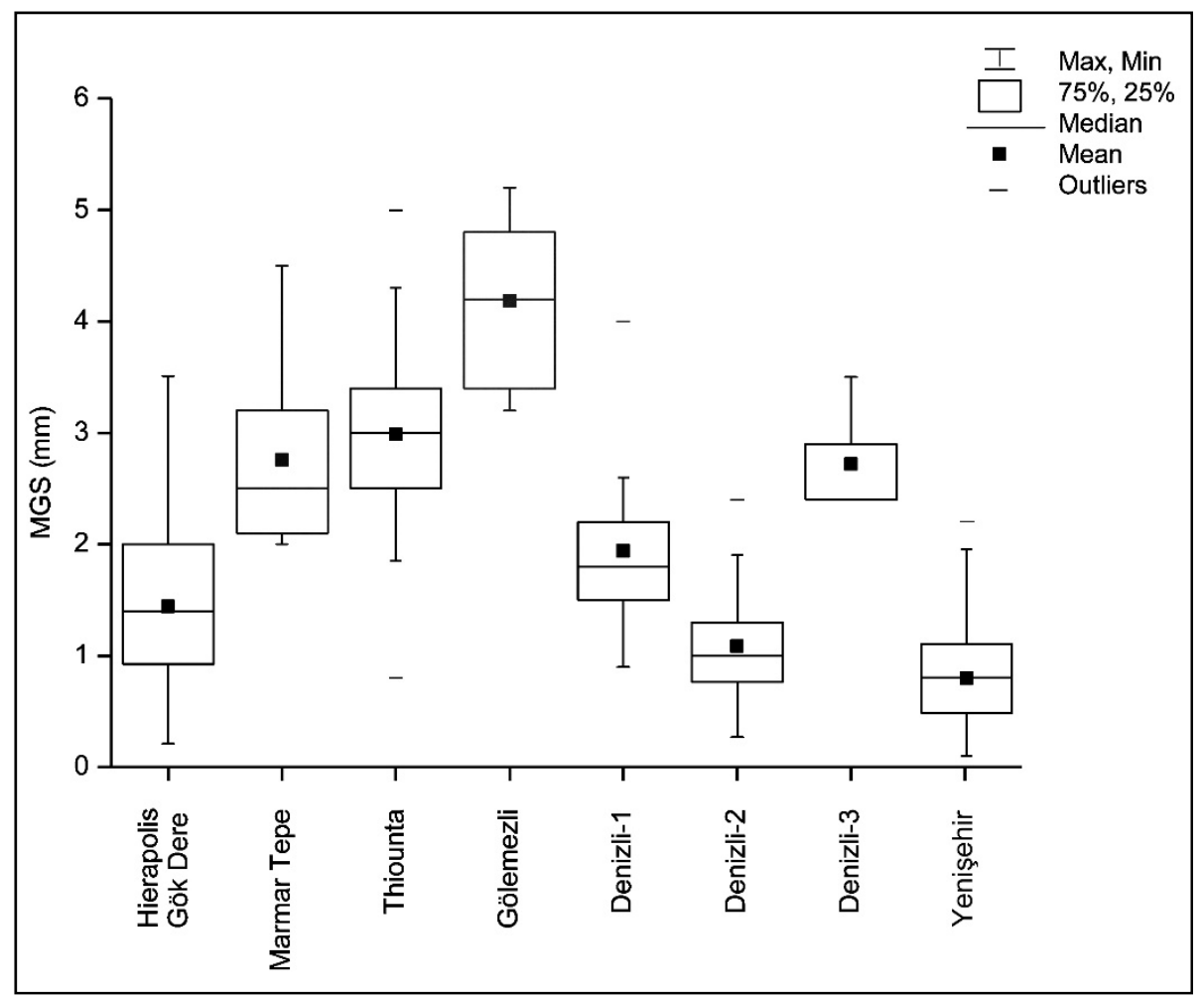

Figure 5. Box and whiskers plot of MGS data of the marble quarries of Lykos valley based on data from [35] (Tables 2.17, 2.18, 2.19), [36] (Figure 6), [37] (Figure 5), [38] (Figure 7). 
The Thiounta marble was quarried close to the ancient village with the same name and located at the northern edge of the Uzunpinar plateau, about $20 \mathrm{~km}$ north of Hierapolis. The main quarry is a large cavity near the edge of the plateau and is characterized by an irregular outline, elongated from north to south $(160 \times 80 \mathrm{~m}), 4-5 \mathrm{~m}$ deep, occupying about 1 hectare. Totally, it is calculated that about $30,000 \mathrm{~m}^{3}$ of material were extracted from this quarry. Other quarries are at various points along the slope leading down towards the Maeander River and they were largely destroyed by the modern extraction activities. The Thiounta marble was extracted not only for the needs of the building sites of Hierapolis, which it reached through the Maeander for a large part of the journey, but also for the artefacts and the construction materials of the main buildings of the village of Thiounta and the other ancient villages in the Uzunpınar plateau and the close Çal plateau. The Thiounta marble is mainly white and sometimes spotted or mottled with veins. The MGS of most samples falls between 2.50 and $3.40 \mathrm{~mm}$. According cathodoluminescence analyses, Thiounta marble exhibits always a dark red uniform texture, low or very low intensity, which is very discriminant for its identification. Moreover, most of C-O isotopic data are grouped in a narrow range, both for carbon and oxygen, between 1.4 and $2.6 \%$ and -4.3 and $-2.8 \%$, respectively. However, some samples representing a grey facies (characterized by MGS values between 2.60 and $3.60 \mathrm{~mm}$ ) fall out of this group, presenting a carbon isotope composition significantly lower. Moreover, other some samples that show an oxygen isotopic composition much lower than the main group could be affected by isotopic alteration.

The Gölemezli marble quarries, in the northern side of the Lykos valley, are about $13 \mathrm{~km}$ north-west of Hierapolis and $7 \mathrm{~km}$ south-east of Tripolis. It is uncertain if they belonged to the territory administered by the first or second city. The extraction area is not very large: five quarries, partially destroyed by the modern resumption of extraction activities, are along the southern slope of the Güneşarkaç Tepe and the south-eastern slope of the Karakuz Tepe. The ancient quarry faces excavated along various hillsides, characterized by a stepped extraction, are between 10 and $37 \mathrm{~m}$ long, and 4-7 $\mathrm{m}$ high. The Gölemezli marble is predominantly white and rarely greyish; sometimes there are rusty coloured veins. It is in general rather compact and bright, and very coarse-grained, with a measured MGS of most samples between 3.40 and $4.80 \mathrm{~mm}$. The isotopic analyses display a narrow range for carbon isotopes from 1.85 to $2.98 \%$ and a less restricted range for oxygen isotopes between -5.79 and $-2.78 \%$. About cathodoluminescence, there are both homogeneous and heterogeneous textures, and the intensity can be very low or medium.

Another important result of the research is the contribution to the identification and characterisation of the marble quarries along the southern side of the Lykos valley $[38,48]$. Indeed, thanks to the integration with previous studies [35] and recent investigations performed by Turkish researchers [36,37], three or four main extraction areas were identified. They are partially destroyed by the modern extraction activities and located quite close among them, along the slopes of the mountains south of the modern city of Denizli, in the territory that was controlled by Laodikeia, about $23-25 \mathrm{~km}$ south-west of Hierapolis. This extraction district, quite large and intensively exploited by Laodikeia, includes the so-called Denizli-1 and Denizli-2 marbles, the Yenişehir marble, and a probably fourth variety named Denizli-3.

The Denizli and Yenişehir marbles are quite compact and with different colours: pure white, white with grey veins, and grey. The Denizli-1 marble was quarried in the southernmost sector of the valley of the river named Domuzderesi, along the eastern slope of the Bozyokuş Tepe, about 4 $\mathrm{km}$ south-west of the modern village of Yeşilköy (included in the southern periphery of Denizli). It has a medium-large grain size with a measured MGS generally between 1.50 and $2.20 \mathrm{~mm}$. Cathodoluminescence is remarkably heterogeneous, showing a range of intensities that span from very low to high. Isotopes range mostly between -2.92 and $-1.85 \%$ for the oxygen and between 1.64 and $3.24 \%$ for the carbon (only two samples fall out of this group).

The Denizli-2 marble (Figure 3E) was quarried in the northernmost sector of the Domuzderesi valley (about $2 \mathrm{~km}$ to the north of the Denizli-1 quarries, along the eastern slope of the Gök Tepe) and especially in the valley of the Kuru Dere, a tributary of Domuzderesi from west. In the last area, 
it was extracted both along the south-eastern slope of the Kuzluk Tepe and on the northern slope of the Bozyokuş Tepe. It has a small grain size with a measured MGS of most samples between 0.75 and $1.35 \mathrm{~mm}$. Isotopes range mostly between -9.59 and $-5.30 \%$ for the oxygen and between -1.44 and $3.41 \%$ for the carbon (only two samples fall out of this group). Cathodoluminescence analyses, available only for two samples, show a homogeneous texture and a very low intensity.

The Yenişehir marble is extracted along the north-western slope of the Gök Tepe (Figure 3F), about $2 \mathrm{~km}$ further north and about $2.3 \mathrm{~km}$ south-west of the modern village of Yenişehir (in the south-western periphery of Denizli), from which the area is accessible. It is very similar to the Denizli-2 marble. Indeed, it has a small grain size with a measured MGS of most samples between 0.50 and $1.22 \mathrm{~mm}$; isotopes range between -10.45 and $-8.56 \%$ for the oxygen and between -1.96 and $3.05 \%$ for the carbon. No cathodoluminescence data are available.

Lastly, it is possible to suppose the existence of a fourth variety (Denizli-3), which was documented by five samples collected in 1970s without a precise location of the sampled quarry. They have a medium-large grain size with a measured MGS generally between 2.40 and $2.90 \mathrm{~mm}$; isotopes are much grouped and range mostly between -2.90 and $-2.69 \%$ for the oxygen and between -0.18 and $0.43 \%$ for the carbon, and they clearly distinguish this variety from the other two. No other mineralogical-petrographic data neither cathodoluminescence data are available.

\subsection{Some Considerations about the Use of Marbles in Hierapolis between the Augustan Age and the Severan Period}

The archaeometric analyses on 340 marble samples collected from archaeological materials of the urban area and necropolises of Hierapolis [39] allowed for the acquisition of very interesting data about the strategies in supplying stone materials for the building sites of the city [49]. The attribution of their provenance from specific extraction areas was based on the use of the database of the quarries in the Lykos valley integrated with the existing databases of white marbles from western Anatolia (such as Aphrodisias, Dokimeion, Göktepe, Miletos, Ephesos, etc.). The assignation procedure was based on the evaluation of the petrographic, $\mathrm{C}-\mathrm{O}$ isotopic and cathodoluminescence characteristics of marbles. In particular, it starts with the evaluation of the petrographic features, followed by the isotopic data, and then the cathodoluminescence in a gradual process of excluding unlikely provenances. At the end of the process, the remaining provenances constitute the most probable ones. Generally, it was usually possible to find one or more elements of certain or probably attribution to one or two quarries, and more rarely to three; very few samples could not be attributed. The final attribution of the provenance of the marbles was also subject to archaeological and art-historical evaluations. In particular, in cases where the three archaeometric analyses provided concordant results, they were always accepted and constitute the final attribution. Whereas, in cases where the three techniques led to two or three possible final attributions, archaeological considerations (quarry distance, transportation costs, function and final use of the artefact) helped to determine the order of likely final attribution.

The archaeometric analyses on archaeological materials from Hierapolis (Figure 6) documented that $90 \%$ of the white, white veined and grey marbles used in the city between the Hellenistic and the Byzantine times came from the quarries located within the territory administered by the city: Marmar Tepe (53\%), Hierapolis-Gök Dere (20\%) and Thiounta (17\%), which was believed to provide the more valuable marble among the local ones according to five funerary inscriptions from the Hierapolitan necropolises explicitly mentioning sarcophagi made of this marble [50]. An extremely limited quantity of material came from the Gölemezli (1\%) and the Denizli-1 and Denizli-2 quarries (1\%). The material imported from the more distant and prestigious quarries of Dokimeion (6\%) and Aphrodisias (1\%) includes for the most part sarcophagi, while the quantity of these marbles used for the architectural and sculptural materials is limited. Finally, the provenance was not identified for only $1 \%$ of the samples, which may also include other imported materials. Moreover, it is important to highlight that the two extraction areas closest to the city together provided $73 \%$ of the material, with a ratio of 
around 2.6:1 between Marmar Tepe and Hierapolis-Gök Dere, which roughly mirrors the extension of the two quarry areas.
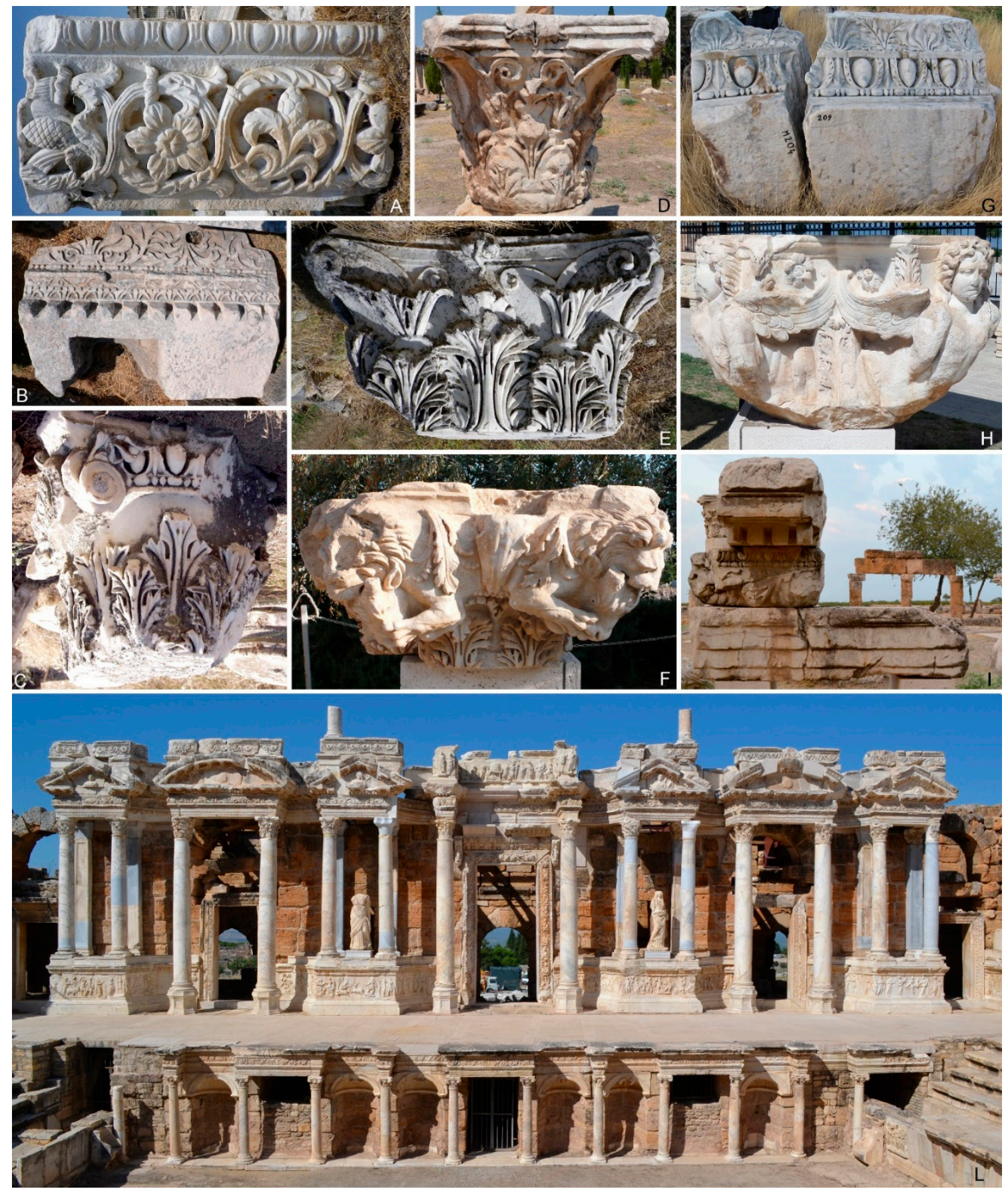

Figure 6. Examples of sampled marble architectural elements from the monuments of Hierapolis: (A-C) Sanctuary of Apollo; (D-I) North Agora; (L) Theatre (first order and logeion of the scaenae frons).

The archaeological materials sampled are highly representative of the Hierapolitan situation in terms of the large number of items, the fact that they include all the types of architectural elements (decorated and not), and as they come from all the necropolises and urban monuments known today. The results of the archaeometric analyses, having been conducted on dated archaeological materials, also provide us with diachronic data on the choices made in the construction sites during the main monumentalization phases and how the Hierapolitan quarries were exploited (Figure 7A). Moreover, 
they allow us to assess in which periods the importation of marbles was especially concentrated, i.e., the Hadrianic, Antonine and Severan Ages.

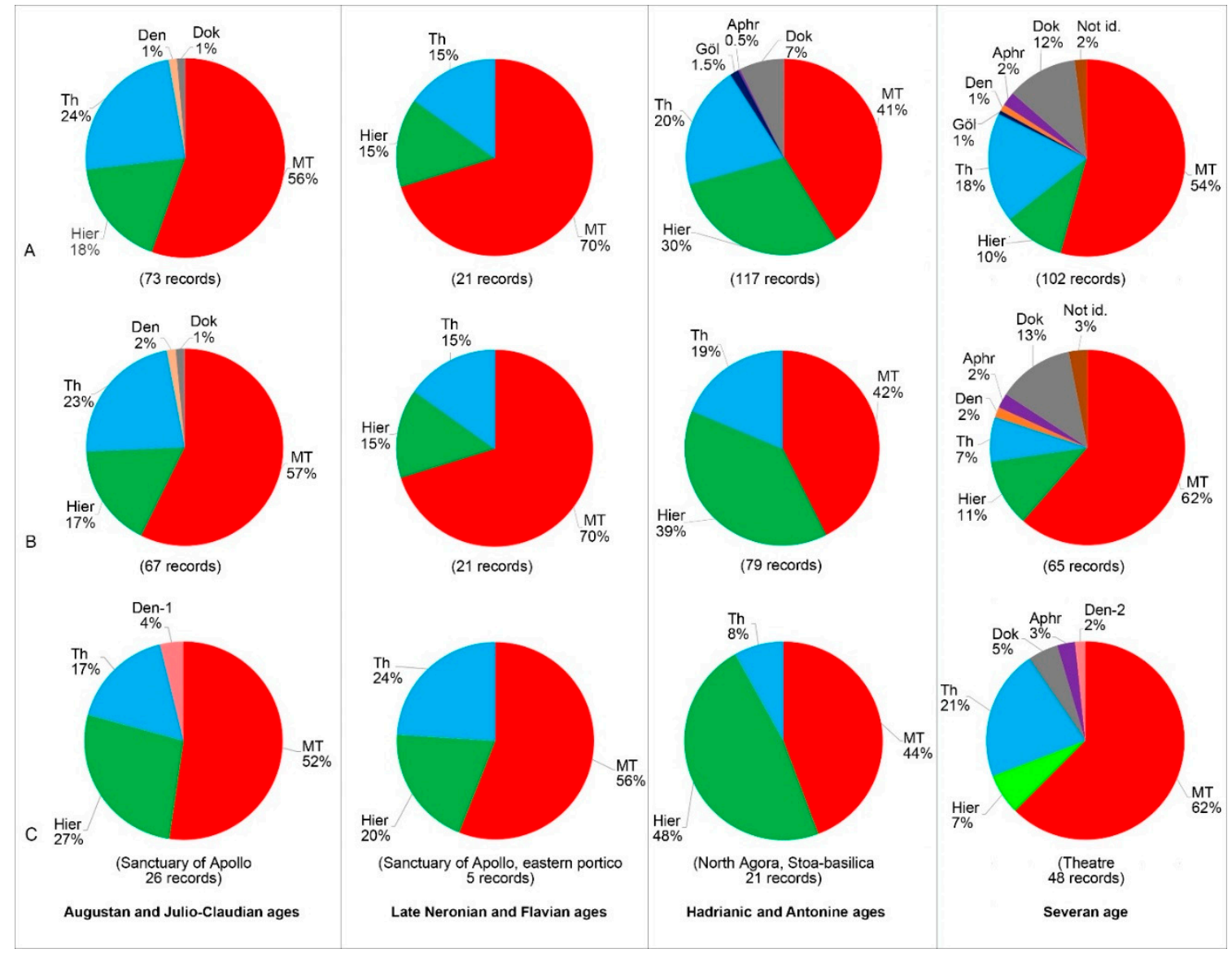

Figure 7. Percentages of marble used in the whole city ((A): urban area and surrounding necropolises), in the public building sites (B) and in four exemplificative monumental complexes (C) between the Augustan age and the Severan period (Aphr = Aphrodisias; Dok = Dokimeion; Den = Denizli; Göl = Gölemezli; Hier = Hierapolis-Gök Dere; MT = Marmar Tepe; Th = Thiounta).

This study offers an opportunity to a short discussion regarding the strategies adopted for supplying the marbles used in the public monuments of the urban area between the Augustan age and the Severan period, i.e., the two centuries and half when are dated the most important building phases of Hierapolis that saw extensive use of these stones. The archaeometric analyses of the sampled architectural elements dated two this period (232 items) documented that local marble was used almost exclusively to construct the large public Hierapolitan complexes (Figure 7B,C), deriving from the quarries of Marmar Tepe (57\%), which supplied a significantly higher quantity of marble than the Hierapolis-Gök Dere (22\%) and Thiounta (13\%) quarries. Whereas, the quantity of marble taken from the Denizli-1 and Denizli-2 quarries was decidedly lower (1\%), while those imported from the more distant quarries of Aphrodisias (1\%) and Dokimeion (4\%) are limited to some particularly valuable sculptural artefacts and architectonic materials (especially column shafts). On the contrary, the Gölemezli, Denizli-3 and Yenişheir quarries seems not used for the city's construction sites. Moreover, at least some of the marbles of unknown provenance $(2 \%)$ should perhaps be added to the imported materials.

In the Augustan period, marble began to acquire an increasingly important role in the public architecture of Hierapolis. As the archaeometric analyses conducted have demonstrated, the demand for this material was largely met by quarries situated within the territory of the city itself, in the districts 
of Marmar Tepe (57\%), Hierapolis-Gök Dere (17\%), both already active from the Hellenistic age (as documented be a few sampled materials from the necropolises), and Thiounta (23\%), while the procurement of white marbles from other extraction areas was extremely limited. Among the monuments of the Augustan and Julio-Claudian eras, particularly significant are those in the Sanctuary of Apollo, where the building works carried out between the end of the 1st cent. BC and the early decades of the 1st cent. AD gave the sacred area the appearance it would maintain for almost two centuries, before its renovation began in the late Antonine era and continued into the Severan age. In the late Augustan-Tiberian period, the renovation of the Hellenistic Temple A led to the creation of a pseudo-monopteros Corinthian temple on a podium, probably made entirely of marble from the Marmar Tepe quarries (although some elements could be also in Thiounta marble); similarly, even the nearby and slightly later small circular monopteros, linked to oracular consultation, was made entirely of Marmar Tepe marble. Started at around the same time, Temple B, the large Ionic peripteral temple dedicated to Apollo Archegetes, also built with contributions from private euergetai, was built with Marmar Tepe and Thiounta marbles. The Doric porticoes delimiting the sanctuary's lower terrace to the north and south, in addition to these two marbles also featured the extensive use of the other local marble, that of Hierapolis-Gök Dere, not seen in the temple buildings: specifically, the entire northern portico, with the exception of the stylobate, seems to have been constructed with this marble. In general, the building activities performed in the sanctuary in this phase were performed using exclusively local marbles, with the exceptions of at least a part of the paving slabs made of white veined marble similar to greco scritto, from the Denizli-1 quarries.

Even the building works of the late Neronian and Flavian eras, after the earthquake of $60 \mathrm{AD}$, reveal that the marbles supplied to the construction sites came exclusively from the local quarries. In particular, Marmar Tepe marble was clearly the most used, even more so than in the previous phase, while the use of Hierapolis-Gök Dere (15\%) and Thiounta (15\%) marbles was considerably less. Exemplificative of this phase is the Corinthian portico delimiting the Sanctuary of Apollo to the east, which was built in the Flavian era mainly using Marmar Tepe marble and with a limited use of Thiounta and Hierapolis-Gök Dere marbles.

In the Hierapolitan public building sites of the Hadrian and Antonine eras the exclusive use of marble extracted from the local quarries for the structural elements is seen, in addition to more limited imports of polychromatic marbles for interior cladding. Unlike in the previous phases, the greater commitment was almost equally divided between the quarries of Marmar Tepe $(42 \%)$ and Hierapolis-Gök Dere $(39 \%)$, the latter in this period seeming to reach the pinnacle of its exploitation; the contribution of the more valuable marble from the Thiounta quarries $(19 \%)$ remains consistent. In this phase, with respect to previous eras, there was a significant increase in the importation of marbles (above all from Dokimeion), but they were used for sarcophagi and not in the public construction sites. The most important monument of this phase is surely the North Agora, an impressive monumental complex with a square measuring $250 \times 125 \mathrm{~m}$, surrounded on three sides by Ionic two-aisle porticoes and on the eastern side by the so-called Stoa-basilica, which was a massive two-storey building around $20 \mathrm{~m}$ high, positioned at the top of a marble staircase $5 \mathrm{~m}$ tall and formed of a central section that projects forward and two Ionic, symmetrical side stoai, with a gallery occupying the entire upper floor. Its construction started in the late Hadrian era and continued for several decades, certainly involving a considerable undertaking for the community of Hierapolis and the demand for very high quantity marble. The most interesting data emerging from the archaeometric analyses is the homogeneity of the marble used to construct the North, West and South Stoai; indeed, the three porticoes were made entirely of marble extracted from the Hierapolis-Gök Dere quarries. Otherwise, the picture that emerges for the Stoa-basilica is more complex: the two lateral stoai seem to be made entirely of marble from the Marmar Tepe quarries, with the exception of the capitals, for which once again Hierapolis-Gök Dere marble was used; the central part seems to be made of Marmar Tepe marble from the bases up to the elements with sphinxes above the pilasters, with the possibility that at least some of these and the elaborate capitals with lions attacking bulls may also be 
made of Thiounta marble. Indeed, the elements of the entablature and the attic reveal the extensive use of Hierapolis-Gök Dere marble together with Marmar Tepe.

It is therefore clear that when the massive monumental complex of the North Agora was designed and the supply strategies for the marble material were planned, the Marmar Tepe quarries alone were not thought capable of providing the materials necessary to construct the monument, but that they would have to be fully supported by the other quarries close to the city, those of Hierapolis-Gök Dere, for the extraction of the enormous quantity of blocks required. The lots of material from the quarries therefore had to be divided: those from Hierapolis-Gök Dere for the North, South and West Stoai around the square, Marmar Tepe marble for the Stoa-basilica, in addition to the support of many other materials from the former quarries, above all for some of the capitals, architraves and cornices. Moreover, it should be noted that marble from the Thiounta quarries was likely also used for some particularly valuable elements with a more complex composition in the Stoa-basilica. Moreover, a distinct characteristic that differentiates the Stoa-basilica from the previous Hierapolitan monuments is that the extensive use of polychromy was recorded for the first time. The marble façade of the building was in fact interrupted in the gallery of the upper floor by a long sequence of two semi-columns attached to pillars and slabs made of polychromatic breccia with a reddish matrix extracted from just north of the city [51]. The widespread use of this particular coloured stone seems to have started in the 2nd century $\mathrm{AD}$ and also continued in the Severan age.

Lastly, the Severan age represents another important phase of monumentalization in Hierapolis, during which works were carried out in the central and northern sectors of the urban area with the construction of new buildings (Nymphaeum of the Sanctuary of Apollo and Nymphaeum of the Tritons) and the radical renovation of some existing monumental complexes, such as the Temple A in the Sanctuary of Apollo and the Theatre. Assessed overall, the building sites of the Severan age are characterized by a return to the extensive use of Marmar Tepe marble (62\%), also including reused material from the older monuments, while the use of marble from Hierapolis-Gök Dere $(11 \%)$ and Thiounta $(7 \%)$ was much less. Compared to the previous phases, the main innovation was however the extensive presence of imported material $(20 \%)$, consisting of specific artefacts (column shafts, capitals, statues), essentially from Dokimeion (13\%) and to a lesser extent from the quarries of Denizli-2 (2\%), Aphrodisias (2\%) and other unidentified extraction districts (3\%). One of the main building sites of this phase is surely the Theatre, set up during the reign of Septimius Severus and completed during the reign of Elagabalus. Such as the Nymphaeum of the Sanctuary of Apollo, built some years before, between the late Antonine age and the early Severan period, its scanae frons, arranged in three orders and $24 \mathrm{~m}$ high overall, was characterized by a clear differentiation between the colonnade (which includes also imported marbles) and the rest of the architectural elements (built using local marble). While the travertine background walls of the logeion and first order or only of the first order was covered by slabs in Dokimeian marble, probably pavonazzetto (also financed by the local purple dyers' guild, as mentioned in the dedicatory inscription of the scaenae frons, dated to 206/207 AD), the architectural elements of the first order seem to be made almost entirely of Marmar Tepe marble, while some elements may be of Thiounta marble. About the 14 monolithic columns-8 (4.02-4.11 m high) on the podia and 6 (5.20-5.35 m high) on the sides of the three main gates-the two shafts that flanked the central Porta Regia were in pavonazzetto columns, while the four contiguous columns, positioned on the podia, were all made of highly veined white marble (perhaps partly intended to imitate pavonazzetto) extracted from the Hierapolis-Gök Dere quarries, although for two of them a provenance from the Denizli-2 quarries cannot be ruled out. The remaining eight columns arranged symmetrically at the two ends of the scaenae frons appear to be made using white or white veined marble from the Marmar Tepe quarries, while their attribution to Thiounta seems less probable. Samples taken from the second and third orders of the scaenae frons only concerned some blocks from the frieze-architraves, which showed considerable homogeneity in the material, again essentially comprised of Marmar Tepe marble, with some elements that may have been made from Thiounta marble. Finally, the logeion, where the back wall was clad with pavonazzetto slabs, was also characterised by the use of a single 
variety of marble, recognized as Marmar Tepe, although it is not possible to entirely rule out the presence of architectural elements made of Thiounta marble.

\subsection{The Quarrying and Use of Alabasters in Hierapolis and in the other City of the Lykos Valley: First Results}

The calcite alabaster quarried in the northern side of the Lykos valley, manly close to Hierapolis but also near the modern village of Gölemezli and the ancient city of Tripolis, was available in varieties that are both coloured (listato and fiorito, generally depending on whether the stone is cut along or against the grain) and completely white (ghiaccione). This calcite alabaster is a compact banded and translucent calcium carbonate stone; in geological terms, it is defined banded travertine [43] (p. 2). In particular, listato alabaster is characterized by veining in more or less densely packed bands, both linear and undulating, with a wide range of shades, among which the most frequent are yellow, reddish brown and rusty red, while fiorito has rounded inclusions of the same colours. Listato and fiorito alabaster has been recognised as the "coloured Hierapolis marble" listed by Strabo (Gheographika, IX, 5, 16) among the coloured marbles brought to Rome in the Augustan period [52,53] (pp. 394-397). Its identification with a marble is due to the shiny effect obtained by smoothing and polishing, while its denomination as Hierapolitan is due to the presence of the most extensive quarries near this city. This alabaster also

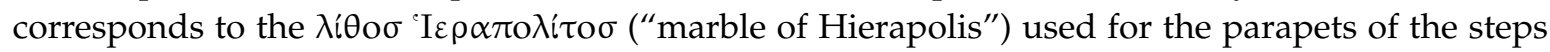
leading up to the ambon of Hagia Sophia in Constantinople (Paulus Silentiarius, Descriptio ambonis, verses 76-104, 264-274), as well as the sarcophagi of Theodora (AD 500-548), wife of Justinian, and the wife of the emperor Anastasios II (who reigned from AD 713 to 715), both of which were once housed in the Church of the Holy Apostles in Constantinople (Constantinus Porphyrogenitus, De cerimoniis aulae Byzantinae, vol. II, chapt. 42, In Heroo Magni Iustiniani, verses 6 and 22).

The archaeological surveys performed in the territory of Hierapolis allowed to identify 21 calcite alabaster quarries at a short distance from the city, within $3 \mathrm{~km}$ of the urban area (Figures 8 and 9A-C), which are grouped in three extraction sites corresponding to the districts of (i) Çukurbağ-Öküzini, (ii) Karakaya-Yarıkkaya-Hanife, and (iii) Yokuşyol-Çallı, located respectively to the west, north-west and north of the city [27]. These quarries generally consist of narrow (2-10 m), deep (5-20 m) and long (from a few dozen metres to more than $100 \mathrm{~m}$ ) vertical-sided trenches, dug for a selective extraction of alabaster included in nearly vertical fissures of travertine-elongated mounds, commonly defined fissure ridges. These landforms are characteristic of some areas in the northern sector of the Denizli basin and derive from the recent geological and structural setting of the area [22,41,42,54-63]. A common characteristic of the fissure ridges is the presence of two types of travertine: (i) the bedded travertine, which is a porous and stratified deposit forming the bulk and flanks of the fissure ridge; and (ii) the banded travertine (i.e., the calcite alabaster), which is a sparitic, nonporous, often subvertical deposit filling veins injected within the interior part of the bedded travertine or sometimes forming sill-like structures along pre-existing travertine strata. In many cases, together with a selective extraction of the banded travertine is also attested the quarrying of blocks of bedded travertine. The amount of extracted alabaster in the area close to Hierapolis is very high; despite some quarries were partially destroyed by the resumption of extraction activities in recent years (see for example Figure 9B), it is calculated that at least $40,500 \mathrm{~m}^{3}$ of material were quarried.

Another important ancient extraction site of calcite alabaster in the northern side of the Lykos valley is $3.5 \mathrm{~km}$ to the north-west of the modern village of Gölemezli, on the southern side of Güneşarkaç Tepe (Figures 9D and 10), about $13 \mathrm{~km}$ north-west of Hierapolis, about $400 \mathrm{~m}$ south-west of the above mentioned Gölemezli marble quarries. In this area, the quarries drew on veins of alabaster found inside fissure ridges that had formed immediately downhill from the master fault (known here as the Akköy or Gölemezli segment), which runs along the north-eastern edge of the Lykos valley $[47,57]$. Until the end of the 20th century, four deep long extraction trenches were visible in this area $[27,52]$, but subsequently they have been destroyed by the modern extraction activities. They were arranged parallel to each other and oriented transversally with respect to the slope of the terrain. These trenches were $30-40 \mathrm{~m}$ long, between 3 and $10 \mathrm{~m}$ wide and up to $10 \mathrm{~m}$ deep. Today it is possible 
to document only a short sector of the northernmost quarry and some large fragments of its faces, which are visible among the spoil from the modern quarry. Overall, it is calculated that about $6400 \mathrm{~m}^{3}$ of material were extracted from these four trenches.

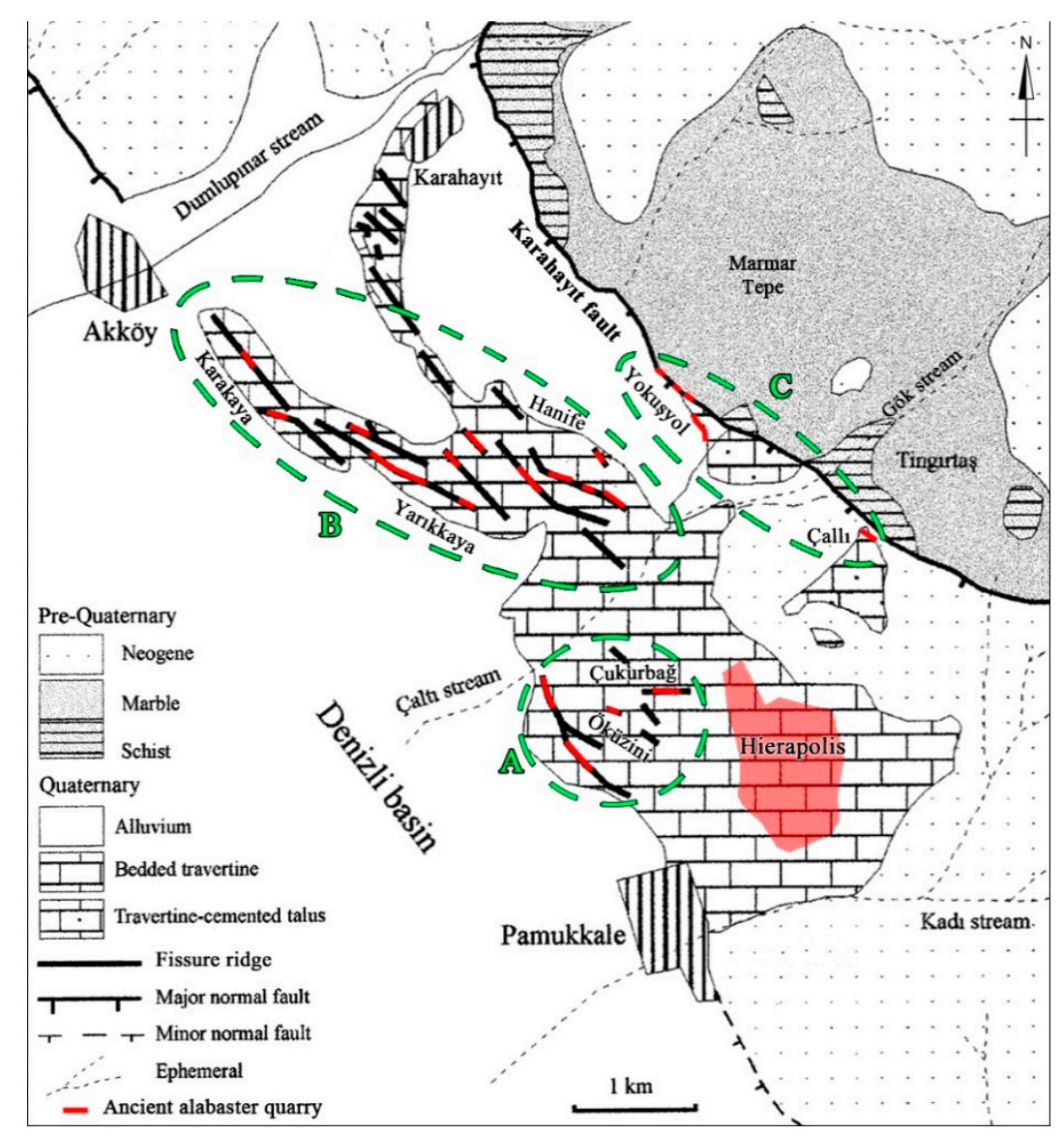

Figure 8. Geological map of the area surrounding Hierapolis and location of the alabaster quarries, modified from [57] (Figure 9). Dashed lines gather the quarries of the three extraction sites: (A) Çukurbağ-Öküzini; (B) Karakaya-Yarıkkaya-Hanife; (C) Yokuşyol-Çallı.

Other important alabaster quarries are about $1.5 \mathrm{~km}$ north-east of Tripolis along the eastern side of the Maeander valley, close to the river, where banded travertines have been found as fissure fillings of variable thickness (up to $15 \mathrm{~m}$ ) within cracks present in the travertine deposits of the Quaternary age $[44,46,64,65]$. The Tripolis alabaster is characterized by coloured bands, generally parallel to each other, which are white, yellowish white, and mostly yellowish-brown, red or reddish-brown. Remains of the ancient quarries, largely destroyed by modern extraction activities, are visible in some sectors of the hillside flanking the river from east for a stretch about $800 \mathrm{~m}$ long (Figures 9E and 11), where working faces still bear nicely preserved cutting marks left by the pickaxes and the pointed chisels. In general, the recent extraction activities still in progress do not allow for determining the extension of the ancient quarries. However, this extraction area seems larger than the Gölemezli quarries, but much smaller than the quarrying areas close to Hierapolis. 


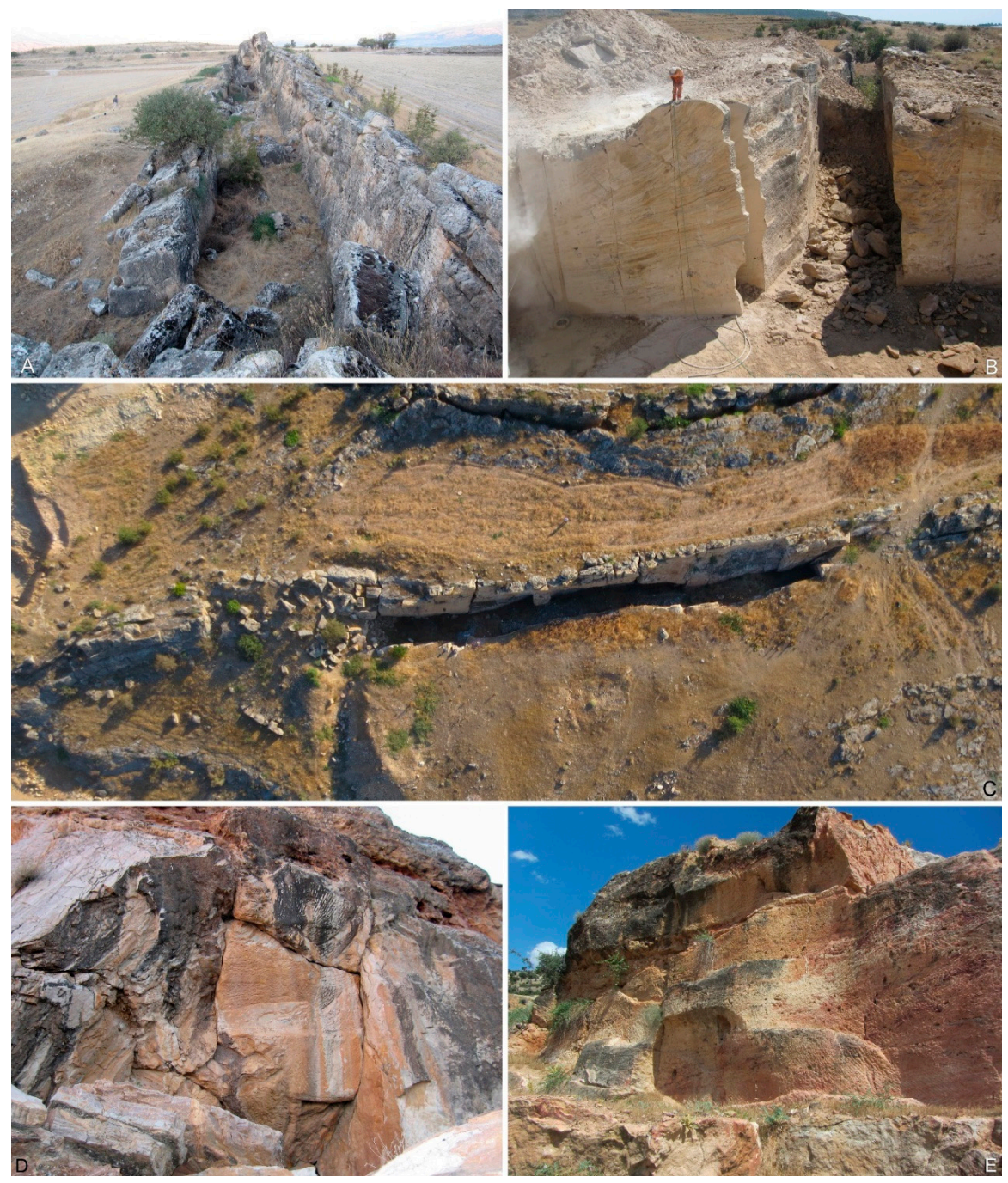

Figure 9. Photographs of alabaster quarries close to Hierapolis ((A-C), respectively in the Çukurbağ, Yarıkkaya and Hanife extraction sites), Gölemezli (D) and Tripolis (E).

The archaeometric characterization of the calcite alabasters extracted close to Hierapolis and at Gölemezli, thanks to stable carbon and oxygen isotopes analyses of 55 samples, allowed for the discrimination among them and between these stones and the other calcite alabasters exploited and exported in antiquity from south-western Anatolia, North Africa (Egypt, Tunisia and Algeria) and Italy $[40,43]$. In particular, it has been demonstrated that the identification of the Hierapolis and Gölemezli alabasters may be remarkably favoured by the fact that it was quarried away from geological deposits, i.e., the banded travertine of fissure-ridges, typical of the specific area, whose genesis process conferred the alabaster a particular stable carbon and oxygen isotope signature. These data were integrated with carbon and oxygen stable isotope compositions of 84 samples of banded travertine from the ancient quarries of the same areas (Table A2 in Appendix A; Figure 12), already available in the geological literature [22,41,42,47]. Moreover, in order to improve the characterisation of this alabaster, the use of diffractometric data showing the presence of calcite and/or aragonite was tested. The results of XRD analyses, again integrated with the XRD data available in the geological literature $[22,41,47,63]$ regarding the banded travertine of the same quarries, show that the samples from Gölemezli and some districts close to Hierapolis (Öküzini, Yokuşyol and Çallı) consist of pure calcite, while the samples from the other Hierapolitan districts (Çukurbağ, Yarıkkaya and Hanife) can be both pure aragonite and calcite or may contain together aragonite and calcite in different proportions (Table 2). 


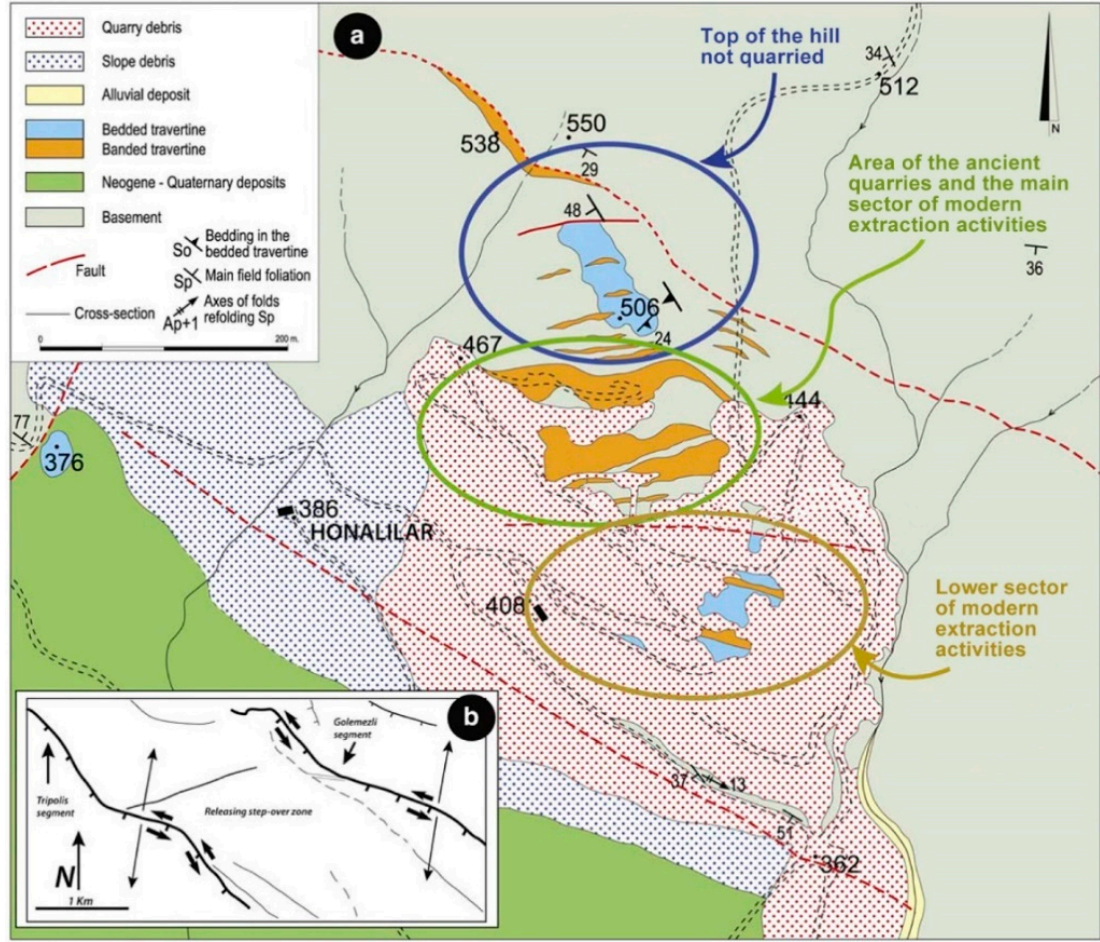

Figure 10. Geological map of the area of the Gölemezli alabaster quarries, modified from [47] (Figure 3.2). The ancient quarried area corresponds to the zone where veins are the thickest and where their spatial distribution is closer.

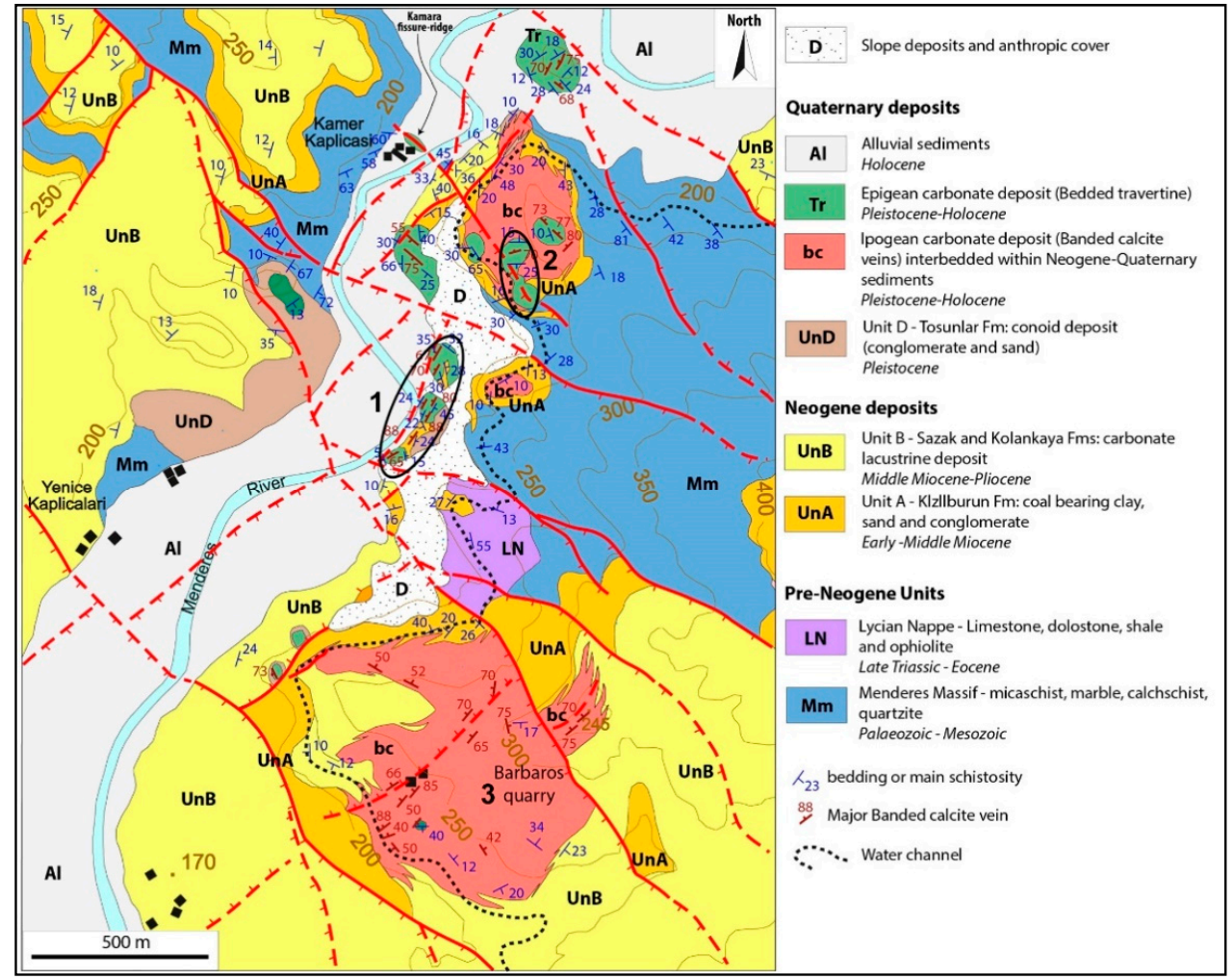

Figure 11. Geological map of the area of the Tripolis alabaster quarries, modified from [44] (Figure 2). 1-2, main sectors characterized by the preservation of some ancient quarry faces; 3, large modern quarry with extraction activities still in progress. 


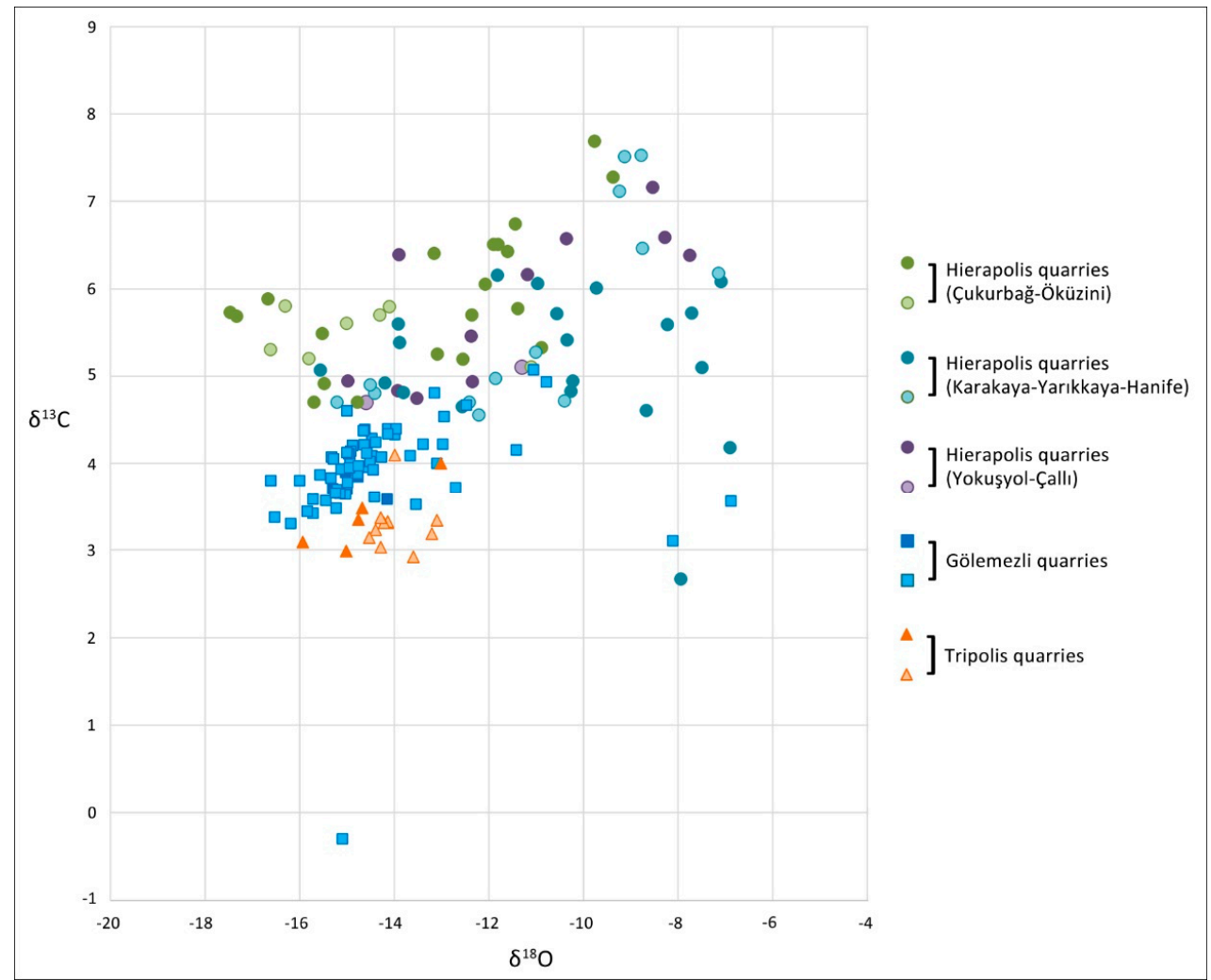

Figure 12. C-O stable isotopes diagram of the alabaster quarries of Hierapolis (the three extraction areas are separated), Gölemezli and Tripolis based on data from archaeometric studies (dark colour symbols) on the ancient extraction sites and geological studies (light colour symbols) on the banded travertine deposits. Data from [43] (Table S1), [46] (Table 2), and [22] (Table 4), [41] (Table 1), [44] (Table 6). Isotopes are expressed versus the V-PDB international standard.

Table 2. Hierapolis, Gölemezli and Tripolis alabaster quarries: presence of calcite/aragonite in the mineralogical composition from XRD analysis. Data from [22] (Table 3), [41] (p. 454), [43] (Table 3), [46] (p. 16, Figure 6), [47] (p. 186).

\begin{tabular}{cccc}
\hline Extraction Site & Calcite & Aragonite & Literature \\
\hline Hierapolis - Çukurbağ & $X$ & $X$ & {$[22,41,43]$} \\
\hline Hierapolis - Öküzini & $X$ & & {$[41,43]$} \\
\hline Hierapolis - Yarıkkaya & $X$ & traces & {$[41,43]$} \\
\hline Hierapolis - Hanife & $X$ & $X$ & {$[41,43]$} \\
\hline Hierapolis - Yokuşyol & $X$ & & {$[41,43]$} \\
\hline Hierapolis - Çallı & $X$ & & {$[43]$} \\
\hline Gölemezli & $X$ & & {$[22,43,47]$} \\
\hline Tripolis & $X$ & traces & {$[46]$} \\
\hline
\end{tabular}

Recently, archaeometric data from the Tripolis quarries have been also available [46]. Even these data can be integrated with C-O isotopic data regarding the banded travertine of the same area [42,44], thus enriching the dataset on the alabaster quarries of the Lykos valley (Table A2 in Appendix A; Figure 12). The stable carbon and oxygen isotope signature of the Tripolis alabaster allows for discriminating it from those extracted close to Hierapolis and Gölemezli. Moreover, XRD analysis [46] indicates calcite mineral as the dominant constituent of the banded travertine samples, with a minor amount of aragonite (Table 2).

The availability of archaeometric data also on the Tripolis quarries allows to examine altogether the data on the alabasters of the Lykos valley and review the results of a recent study [43] aimed at determining the quarry provenance of the alabaster used for 15 archaeological materials from 
Hierapolis (where this stone is largely used: Figure 13A-G) using C-O stable isotope and XRD analyses. Indeed, this study, not having data on Tripolis quarries, showed that the provenance of the alabaster used for these artefacts, dated to the Roman Imperial period and the Byzantine age, is about $56 \%$ from Gölemezli and $44 \%$ from the quarries closest to Hierapolis. Now, the comparison of the archaeometric data of samples from the Hierapolitan archaeological materials with those of the complete database of the alabaster quarries of the Lykos valley shows partially different results (Figure 14; Table 3). Indeed, the attribution to the Hierapolis and Gölemezli quarries is confirmed for seven samples (respectively H13_078, H13_120, H13_232 to Hierapolis and H13_109, H13_172, H13_213, H13_303 from Gölemezli), but new attributions are possible for the other samples. In particular, a provenance from the Tripolis quarries is possible for the alabaster of two samples (H13_058, H13_161), other two samples can be attributed to the Gölemezli quarries (H13_079, H13_214), while the attribution of the other four samples can be changed as (H13_173, H13_211, H13_217, H13_233) remains uncertain among the three extraction areas of the Lykos valley. Moreover, even the attribution of five samples collected from archaeological materials of Tripolis (where alabaster is largely used for column shafts-Figure 13I-column base, opus sectile, cladding of walls, and base of statue) can be reviewed. Indeed, in [46] (pp. 14 and 17; fig. 12c) they have been generically attributed to the Tripolis quarries using an incomplete dataset of archaeometric data of the quarries of the Lykos valley. Considering all the available data (Figure 14; Table 3) is now possible to attribute to the Tripolis quarries only two samples (TRP-9 and TRP-24, the second of which is uncertain), while the provenance of the other samples can be attributed to the Hierapolis quarries (TRP-16) or is uncertain between these and the Gölemezli and Tripolis quarries (TRP-20, TRP-29).

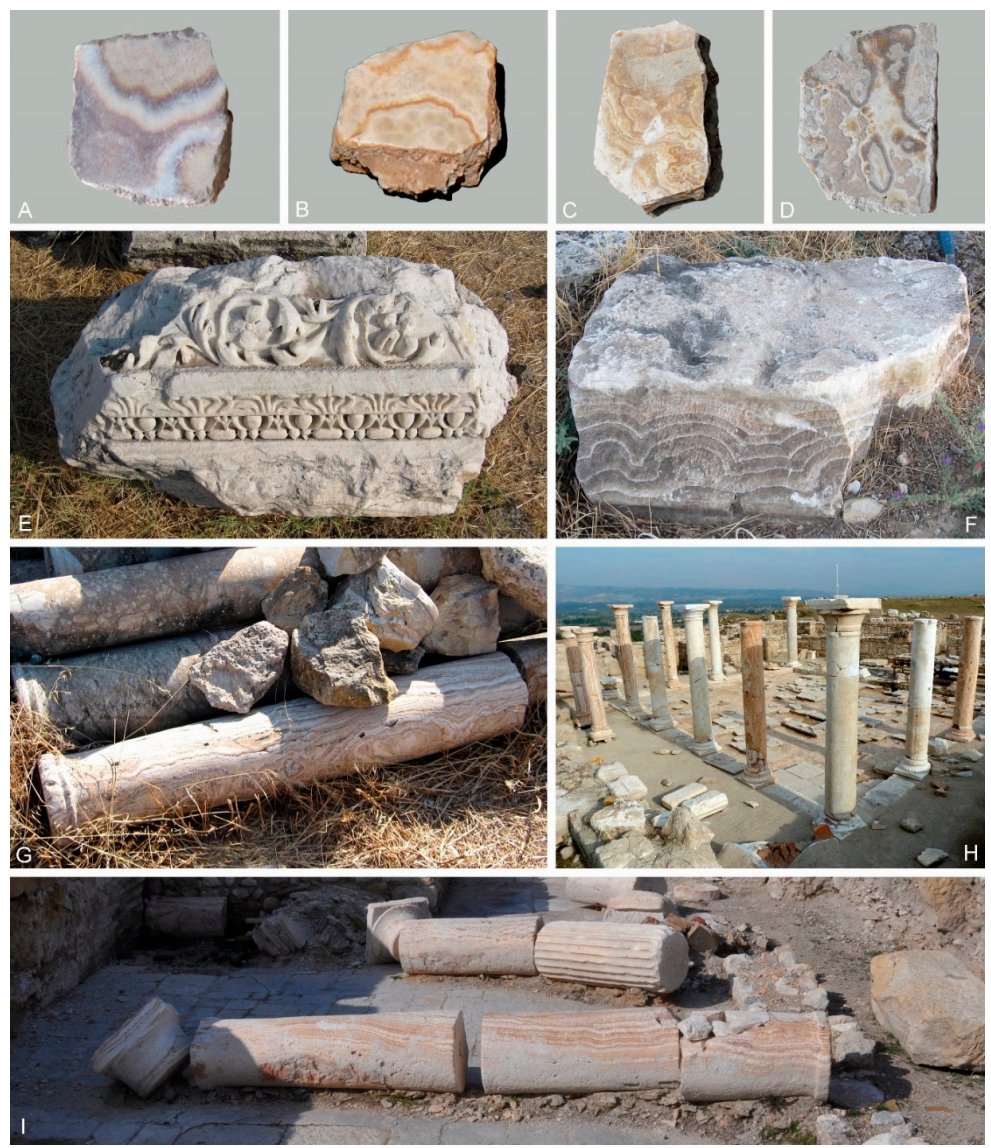

Figure 13. Some sampled alabaster architectural elements from Hierapolis $((\mathbf{A})=$ H13_232, (B) $=$ H13_303, (C) = H13_217, (D) = H13_233, (E) = H13_173, (F) = H13_213, (G) = H13_058) and examples of alabaster column shafts from Laodikeia $(\mathbf{H})$ and Tripolis (I). 


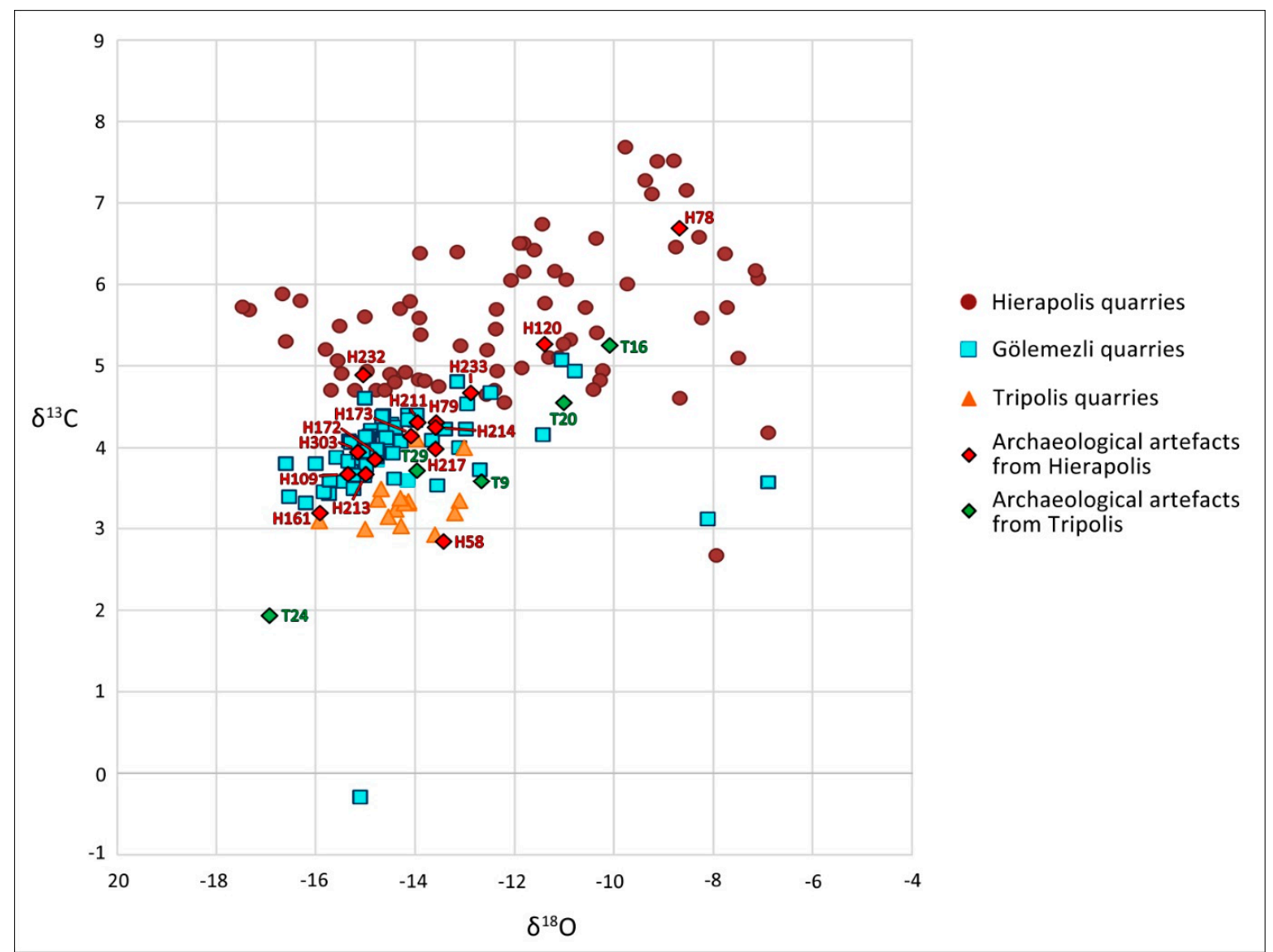

Figure 14. Diagram of the C-O stable isotopes distribution of the alabaster artefacts from Hierapolis $(\mathbf{H})$ and Tripolis $(\mathbf{T})$ in comparison with the data of the ancient quarries of Hierapolis, Gölemezli and Tripolis. Isotopes are expressed versus the V-PDB international standard.

Although the number of analysed archaeological samples is not high enough to allow us to formulate a detailed reconstruction of the procurement strategies of alabasters for the Hierapolis ancient building sites, however these first results are very interesting because they show the exclusive procurement of this stone from the local extraction areas of the Lykos valley and the important role of the Gölemezli quarries, in contrast with the scarce use in Hierapolis of the Gölemezli white marble (as we have seen above in Section 3.2). This question, which is strictly linked to that of the city who controlled and managed this site (Hierapolis or the closer Tripolis), will be investigated analysing a larger number of archaeological artefacts by future research. Indeed, the few data available for the archaeological materials from Tripolis seem to suggest the exploitation also of the Gölemezli quarries, but this question too will have to be investigated in the next research. Lastly, another important information from the archaeometric analyses of archaeological materials is that Hierapolis used alabaster from the quarries of Tripolis and vice versa. This can be connected to the purchase of particular batches of materials, chosen according to the particular colour of the stone, the type of architectural element to be created or for other reasons that only a deepening of the research and the analysis of a large number of samples from archaeological materials can explain. 
Table 3. Provenance of the alabaster used for some exemplificative architectural elements from Hierapolis and Tripolis. C-O stable isotopic composition and content of calcite/aragonite from [43] (Table 2), [45] (Figure 6), [46] (Table 2, Figure 6); XRD data about the content of calcite/aragonite are not available (n.a.) for sample TRP-24. Previous attributions from [43] (Table 2; Figures 8-9) and [46] (pp. 14, 17; Figure 12c) are compared with new possible attributions based on a larger dataset of archaeometric data on the alabaster quarries of Lykos valley; the names of the quarries are shown in order of greater probability.

\begin{tabular}{|c|c|c|c|c|c|c|c|}
\hline City & Sample & $\begin{array}{l}\delta^{18} \mathrm{O} \\
\text { (PDB) }\end{array}$ & $\begin{array}{c}\delta^{13} C \\
(\mathrm{PDB})\end{array}$ & Calcite & Aragonite & Previous Attribution & $\begin{array}{c}\text { Possible New } \\
\text { Attribution }\end{array}$ \\
\hline Hierapolis & H13_058 & -13.43 & 2.84 & $x$ & & Gölemezli (?) & Tripolis \\
\hline Hierapolis & H13_078 & -8.68 & 6.69 & $x$ & & Hierapolis & Hierapolis \\
\hline Hierapolis & H13_079 & -13.57 & 4.31 & $x$ & & Gölemezli, Hierapolis & Gölemezli \\
\hline Hierapolis & H13_109 & -15.35 & 3.67 & $x$ & & Gölemezli & Gölemezli \\
\hline Hierapolis & H13_120 & -11.39 & 5.27 & $x$ & & Hierapolis & Hierapolis \\
\hline Hierapolis & H13_161 & -15.92 & 3.19 & $x$ & traces & Gölemezli (?) & Tripolis \\
\hline Hierapolis & H13_172 & -14.80 & 3.85 & $x$ & & Gölemezli & Gölemezli \\
\hline Hierapolis & H13_173 & -14.08 & 4.14 & $x$ & & Gölemezli, Hierapolis & $\begin{array}{c}\text { Tripolis, } \\
\text { Gölemezli (?) }\end{array}$ \\
\hline Hierapolis & H13_211 & -13.95 & 4.31 & $x$ & & Gölemezli, Hierapolis & $\begin{array}{l}\text { Gölemezli, } \\
\text { Tripolis (?) }\end{array}$ \\
\hline Hierapolis & H13_213 & -14.99 & 3.67 & $x$ & & Gölemezli & Gölemezli \\
\hline Hierapolis & H13_214 & -13.59 & 4.25 & $x$ & & Gölemezli, Hierapolis & Gölemezli \\
\hline Hierapolis & H13_217 & -13.59 & 3.98 & $x$ & & Gölemezli, Hierapolis & $\begin{array}{l}\text { Gölemezli, } \\
\text { Tripolis (?) }\end{array}$ \\
\hline Hierapolis & H13_232 & -15.04 & 4.89 & & $X$ & Hierapolis & Hierapolis \\
\hline Hierapolis & H13_233 & -12.88 & 4.67 & $x$ & & Hierapolis & $\begin{array}{c}\text { Hierapolis, } \\
\text { Gölemezli (?) }\end{array}$ \\
\hline Hierapolis & H13_303 & -15.15 & 3.94 & $x$ & & Gölemezli & Gölemezli \\
\hline Tripolis & TRP-9 & -12.67 & 3.58 & $X$ & & Tripolis & Tripolis \\
\hline Tripolis & TRP-16 & -10.08 & 5.25 & $X$ & & Tripolis & Hierapolis \\
\hline Tripolis & TRP-20 & -11.00 & 4.55 & $x$ & & Tripolis & $\begin{array}{c}\text { Hierapolis, } \\
\text { Gölemezli (?) }\end{array}$ \\
\hline Tripolis & TRP-24 & -16.93 & 1.93 & n.a. & n.a. & Tripolis & Tripolis (?) \\
\hline Tripolis & TRP-29 & -13.96 & 3.72 & $x$ & & Tripolis & $\begin{array}{l}\text { Gölemezli, } \\
\text { Tripolis (?) }\end{array}$ \\
\hline
\end{tabular}

\section{Conclusions and Further Research Perspectives}

The multidisciplinary research performed in recent years has made it possible to build a solid base of knowledge on many aspects of the history of Hierapolis, such as (i) the exploitation of the natural resources of the territory, (ii) the detailed archaeometric characterization of the white marble quarries of its territory and the whole Lykos valley (which enrich the reference databases used for determining the provenance of marbles used in antiquity), (iii) the building stone procurement strategies adopted during the city's long life. Indeed, while on one hand the systematic study and detailed characterization of the quarries enabled precise determination of the provenance of the marbles used in the building sites, on the other, the extensive knowledge of the building phases of the monumental complexes made it possible to diachronically determine the contribution of the various local quarrying districts.

The picture of Hierapolis that emerges from this study can be considered exemplary of many cities in the Empire that were located in areas rich in marble quarrying districts, and specifically inland towns in Asia Minor. Although these cities had sprung up along important terrestrial and fluvial communication routes, they were distant from the main maritime commercial networks. Hierapolis is thus characterized by a substantial self-sufficiency in the procurement of stones for construction, with limited imports from the nearby prestigious marble quarries of Dokimeion and Aphrodisias. Indeed, the city lay within an extensively exploited quarrying district that was able to meet local demand for white, grey, and veined white marbles (the $90 \%$ of which is from the local quarries of 
Marmar Tepe, Hierapolis-Gök Dere and Thiounta, all surely located within the territory administered by the city), as well as coloured varieties and stones (alabasters and breccias) that closely resembled the most prestigious and popular varieties on a supra-regional level. These results are very similar, for example, to those achieved by recent investigations carried out in another city of Asia Minor located in a rich extractive district, Aphrodisias, which during the Imperial age used quite exclusively local marbles for architectural elements and sculptures [66,67], with only limited importations from other districts, such as Dokimeion and also Hierapolis (for the alabaster) [66] (p. 189, note 81), [68] (p. 149).

The archaeological investigations in Hierapolis, and in the other cities of Lykos valley, highlighted a large use of the calcite alabaster (ghiaccione, listato and fiorito varieties) together with white, grey, and veined white marbles. While ghiaccione alabaster (the less common variety) was used as a white marble, the listato and fiorito alabaster, largely available in the northern sector of the valley, constituted the only local coloured marble together with the polychromatic breccia. If for the white marbles the research is at a very advanced level, the investigations about alabasters are at a starting point, but the first results are very interesting. Indeed, the integration of available archaeometric data allow for a sufficient characterization of the alabaster quarries of the Lykos valley, useful to distinguish among them the three main extraction districts (Hierapolis, Gölemezli and Tripolis). Moreover, these data allow for distinguishing the alabasters extracted from the quarries in the Lykos valley and the other calcite alabasters extracted in antiquity in southwestern Turkey (close to the ancient city of Thyatira), northern Africa (Egypt, Tunisia and Algeria), and in Italy [40]. Thus, it will be possible to determine the true extent of the export of the coloured marble of Hierapolis (i.e., the alabaster quarried in the Lykos valley, in particular close to this city) during the Roman age and Byzantine period. About archaeological materials, recent studies $[43,46]$ have demonstrated the possibility of determining the quarry provenance of the alabaster thanks to the analyses of carbon and oxygen stable isotopes in integration with XRD analyses. In this regard, the present study shows the need to use a reference database of the quarries as rich as possible. However, only the archaeometric analyses of a large number of sampled archaeological materials will allow for the formulation of detailed reconstruction of the procurement strategies of alabasters for the Hierapolis ancient building sites. Moreover, this research could be extended also to Tripolis, where the alabaster was extensively used, and Laodikeia, where this stone was used (Figure 13H), but less extensively than Hierapolis and Tripolis, probably due to the fact that the city on the Lykos had no quarries of this stone in its territory. Lastly, future research will be also aimed at a better archaeometric discrimination among the three quarry areas (Çukurbağ-Öküzini, Karakaya-Yarıkkaya-Hanife, Yokuşyol-Çallı) closest to Hierapolis in order to study and reconstruct the strategies of exploitation of the different extraction areas in relation to the building sites of the city, also in a diachronic perspective, as for the marble quarries. Indeed, recent investigations [43] have highlighted that it is not possible to obtain univocal attribution of archaeological samples to these quarry areas.

Funding: This research was funded by the Italian Ministry of Education, University and Research (MIUR), as part of the FIRB 2012 and PRIN 2015 programmes, and by CNR, as part of the Laboratori Archeologici Congiunti 2016-2017 programme.

Acknowledgments: This research was performed as a part of the Marmora Phrygiae Project, coordinated by Giuseppe Scardozzi and carried out in the years 2013-2016 by three Institutes of the National Research Council of Italy (IBAM-Istituto per i Beni Archeologici e Monumentali, lead partner; ICVBC-Istituto per la Conservazione e la Valorizzazione dei Beni Culturali; IGAG-Istituto di Geologia Ambientale e Geo-ingegneria) and the University of the Salento (Dipartimento di Beni Culturali), within the investigation activities of the Italian Archaeological Mission at Hierapolis directed by Francesco D'Andria (University of Salento). The project was funded by the Italian Ministry of Education, University and Research (MIUR), as part of the FIRB 2012 programme. Many thanks to the researchers involved in the Marmora Phrygiae Project and especially to Tommaso Ismaelli, for the supporting in the coordination of research activities and the helpful discussions about the archaeological data and monuments, Mauro Brilli and Francesca Giustini (CNR-IGAG), who performed the geo-chemical analyses, Emma Cantisani (CNR-ICVBC) and Giovanni Quarta (CNR-IBAM), who carried out the petrographic investigations on marbles, Maria Pilar Lapuente Mercadal (UEA-ICAC), who coordinated the cathodoluminescence analyses, and Giacomo Di Giacomo, Immacolata Ditaranto and Ilaria Miccoli (CNR-IBAM), who cooperated in the archaeological surveys of marble and alabaster quarries. The research prosecuted by CNR-IBAM as a part of the Multidisciplinary 
Laboratory of Excavations in the Lykos Valley Project, coordinated by Giuseppe Scardozzi and funded by CNR (Laboratori Archeologici Congiunti 2016-2017 programme), and the Project Archeologia dei paesaggi urbani in Asia Minore tra tardo ellenismo ed età bizantina. Approcci multidisciplinari allo studio di Hierapolis di Frigia, coordinated by Grazia Semeraro (University of Salento) and funded by MIUR (PRIN 2015 programme).

Conflicts of Interest: The author declare no conflict of interest.

\section{Appendix A}

Table A1. Colour, calcite (CC) or dolomite (Dol) mineralogy by XRD, MGS (mm), and stable oxygen and carbon isotope data of the whole set of samples collected in the marble quarries of Lykos valley. Data from [35] (Tables 2.17, 2.18, 2.19), [36] (Figure 6, Table 7), [37] (Figure 5, Table 2), [38] (Tables 2-3). Note that in [35] colour is expressed in numeric values according to a grey scale where 0 represents black and 255 white. Moreover, it is important to highlight that in [36,37] MGS (Maximum Grain Size) measures and calcite/dolomite compositions are not available for each sample, but this information is reported grouped for each variety of marble (white, grey veined and grey); so, the MGS measures of $[36,37]$ are integrated in Figure 5, while the calcite/dolomite compositions are integrated in Table 1. For the cathodoluminescence features of a large group of these samples, synthetized in Table 1, see [38] (Table 2).

\begin{tabular}{|c|c|c|c|c|c|c|c|}
\hline Sample & Colour & $\mathrm{CC}$ & Dol & MGS & $\begin{array}{c}\delta^{13} \mathrm{C} \\
\text { (PDB) }\end{array}$ & $\begin{array}{c}\delta^{18} \mathrm{O} \\
\text { (PDB) }\end{array}$ & Lit \\
\hline \multicolumn{8}{|c|}{ Hierapolis-Gök Dere } \\
\hline M1-1 & grey & $x$ & & 3.00 & 0.70 & -10.05 & [38] \\
\hline M1-2 & grey & $x$ & & 2.30 & 1.07 & -9.00 & [38] \\
\hline M1-3 & grey & $x$ & & 2.20 & 0.66 & -9.22 & [38] \\
\hline M1-4 & grey & $x$ & & - & 0.26 & -8.31 & [38] \\
\hline M1-5 & grey & $x$ & & - & 0.95 & -9.49 & [38] \\
\hline M1bis-1 & white/yellowish & $x$ & & 2.15 & 0.67 & -7.62 & [38] \\
\hline M1bis-2 & white/yellowish & $x$ & & - & 0.87 & -7.37 & [38] \\
\hline M1bis-3 & white/yellowish & $x$ & & 2.60 & 1.80 & -8.49 & [38] \\
\hline M1bis-4 & white/yellowish & $x$ & & - & 1.63 & -9.27 & [38] \\
\hline M1bis-5 & white/yellowish & $x$ & & - & 1.31 & -9.02 & [38] \\
\hline M1bis-6 & white/yellowish & $x$ & & - & 0.96 & -8.81 & [38] \\
\hline M2-1 & white & $x$ & \pm & 1.40 & 1.85 & -7.05 & [38] \\
\hline M2-2 & white veined & $x$ & & 1.60 & 1.90 & -7.10 & [38] \\
\hline M2-3 & white & $x$ & & 1.80 & 1.12 & -7.32 & [38] \\
\hline M2-4 & white & $x$ & & - & 0.77 & -7.39 & [38] \\
\hline M2-5 & white & $x$ & & - & 1.36 & -7.74 & [38] \\
\hline M2-6 & white & $x$ & & - & 2.48 & -8.06 & [38] \\
\hline M2bis-1 & white & $x$ & \pm & 1.20 & 3.68 & -6.92 & [38] \\
\hline M2bis-2 & white & $x$ & & 1.40 & -0.46 & -8.39 & [38] \\
\hline M2bis-3 & white & $x$ & & - & 3.34 & -6.84 & [38] \\
\hline M2bis-4 & white & $x$ & & - & 3.69 & -6.16 & [38] \\
\hline M4-1 & white & $x$ & & 2.00 & -0.74 & -6.58 & [38] \\
\hline M4-2 & white & $x$ & & - & 0.96 & -6.74 & [38] \\
\hline M5-1 & white & $x$ & & 2.00 & 0.17 & -8.33 & [38] \\
\hline M5-2 & white & $x$ & & 1.60 & -0.02 & -8.45 & [38] \\
\hline M5-3 & white & $x$ & & 2.00 & 0.09 & -7.41 & [38] \\
\hline M5-4 & white & $x$ & & 1.30 & 2.06 & -8.98 & [38] \\
\hline M5-5 & white & $x$ & \pm & - & 0.06 & -8.01 & [38] \\
\hline M5-6 & white & $x$ & & - & 2.83 & -8.67 & [38] \\
\hline M5bis-1 & black & $x$ & \pm & & 2.60 & -6.95 & [38] \\
\hline M5bis-2 & black & $x$ & \pm & & 2.05 & -7.76 & [38] \\
\hline M5bis-3 & black & $x$ & \pm & & 2.16 & -7.86 & [38] \\
\hline M5bis-4 & black & $x$ & \pm & & 3.11 & -5.73 & [38] \\
\hline M5bis-5 & black & $x$ & & & 3.35 & -5.87 & [38] \\
\hline M5bis-6 & layered black/white & $x$ & \pm & & 2.71 & -6.54 & [38] \\
\hline CV1 & 229 & $x$ & & 1.40 & 2.62 & -7.71 & [35] \\
\hline CV2 & 216 & $x$ & \pm & 1.30 & 2.91 & -7.59 & [35] \\
\hline CV3 & 214 & $x$ & & 1.60 & 2.57 & -7.16 & [35] \\
\hline CV4 & 220 & $x$ & & 1.70 & 1.37 & -7.64 & [35] \\
\hline CV5 & 219 & $x$ & & 1.60 & 0.66 & -7.32 & [35] \\
\hline CV6 & 217 & $x$ & & 2.00 & 2.52 & -7.82 & [35] \\
\hline CV7 & 223 & $x$ & & 1.40 & -0.37 & -7.98 & [35] \\
\hline CV8 & 219 & $x$ & & 1.40 & 2.33 & -7.52 & [35] \\
\hline CV9 & 223 & $x$ & & 1.20 & 3.40 & -7.01 & [35] \\
\hline CV10 & 186 & $x$ & & 1.80 & 0.77 & -9.57 & [35] \\
\hline
\end{tabular}


Table A1. Cont.

\begin{tabular}{|c|c|c|c|c|c|c|c|}
\hline Sample & Colour & $\mathrm{CC}$ & Dol & MGS & $\begin{array}{c}\delta^{13} \mathrm{C} \\
\text { (PDB) }\end{array}$ & $\begin{array}{c}\delta^{18} \mathrm{O} \\
\text { (PDB) }\end{array}$ & Lit \\
\hline \multicolumn{8}{|c|}{ Hierapolis-Gök Dere } \\
\hline CV11 & 212 & $x$ & & 1.50 & 2.00 & -8.82 & [35] \\
\hline HCV1.1 & 218 & $x$ & & 3.20 & 1.10 & -9.31 & [35] \\
\hline HCV1.2 & 214 & $x$ & & 1.30 & 3.05 & -8.13 & [35] \\
\hline HCV1.3 & 197 & $x$ & & 1.40 & 1.01 & -7.87 & [35] \\
\hline HCV1.4 & 224 & $x$ & & 1.10 & 3.12 & -7.48 & [35] \\
\hline HCV1.5 & 180 & $x$ & & 1.00 & 1.17 & -7.31 & [35] \\
\hline HCV2.1 & 216 & $x$ & & 1.30 & 3.15 & -7.65 & [35] \\
\hline HCV2.2 & 227 & $x$ & & 1.70 & 3.10 & -7.15 & [35] \\
\hline HCV2.3 & 187 & $x$ & & 1.30 & 2.70 & -8.87 & [35] \\
\hline HCV2.4 & 224 & $x$ & & 1.40 & 2.01 & -9.17 & [35] \\
\hline HCV4.1 & 217 & $x$ & & 1.40 & 0.91 & -7.69 & [35] \\
\hline HCV4.2 & 196 & $x$ & & 3.10 & 1.20 & -8.50 & [35] \\
\hline HCV4.3 & 222 & $x$ & & 2.80 & 0.37 & -9.45 & [35] \\
\hline HCV4.4 & 215 & $x$ & & 2.50 & 0.84 & -8.59 & [35] \\
\hline HCV4.5 & 224 & $x$ & & 2.60 & 0.69 & -8.24 & [35] \\
\hline HCV4.6 & 165 & $x$ & & 1.90 & 0.91 & -7.26 & [35] \\
\hline HCV4.7 & 198 & $x$ & & 2.00 & 1.46 & -9.45 & [35] \\
\hline HCV4.8 & 208 & $x$ & & 2.00 & 1.22 & -8.10 & [35] \\
\hline HCV4.9 & 224 & $x$ & & 2.60 & 0.98 & -7.83 & [35] \\
\hline HCV4.10 & 208 & $x$ & & 2.80 & 1.22 & -8.64 & [35] \\
\hline HCV4.11 & 225 & $x$ & & 3.40 & 0.02 & -7.91 & [35] \\
\hline HRP-1 & white & - & - & - & 3.22 & -8.62 & [36] \\
\hline HRP-2 & white & - & - & - & 2.57 & -8.16 & [36] \\
\hline HRP-7 & white & - & - & - & 3.52 & -7.32 & [36] \\
\hline HRP-9 & white & - & - & - & 2.15 & -8.22 & [36] \\
\hline HRP-18 & white & - & - & - & 2.09 & -9.35 & [36] \\
\hline HRP-19 & white & - & - & - & 1.78 & -7.82 & [36] \\
\hline HRP-28 & white & - & - & - & 3.45 & -7.65 & [36] \\
\hline HRP-3 & grey veined & - & - & - & 0.69 & -7.67 & [36] \\
\hline HRP-4 & grey veined & - & - & - & 0.63 & -9.55 & [36] \\
\hline HRP-10 & grey veined & - & - & - & 2.66 & -5.76 & [36] \\
\hline HRP-21 & grey veined & - & - & - & 2.87 & -6.40 & [36] \\
\hline HRP-22 & grey veined & - & - & - & 2.66 & -6.93 & [36] \\
\hline HRP-23 & grey veined & - & - & - & 2.40 & -6.97 & [36] \\
\hline HRP-24 & grey veined & - & - & - & 3.08 & -6.00 & [36] \\
\hline HRP-5 & grey & - & - & - & 3.02 & -7.24 & [36] \\
\hline HRP-8 & grey & - & - & - & 3.06 & -4.53 & [36] \\
\hline HRP-11 & grey & - & - & - & 2.41 & -6.19 & [36] \\
\hline HRP-12 & grey & - & - & - & 3.11 & -6.37 & [36] \\
\hline HRP-15 & grey & - & - & - & 3.12 & -6.49 & [36] \\
\hline HRP-16 & grey & - & - & - & 2.77 & -6.84 & [36] \\
\hline \multicolumn{8}{|c|}{ Marmar Tepe } \\
\hline Mtgrigio & grey & $x$ & & - & 0.93 & -1.98 & [38] \\
\hline MT29-1 & white & $x$ & & 3.40 & 1.92 & -4.40 & [38] \\
\hline MT29-2 & white & $x$ & & 2.20 & 1.98 & -2.94 & [38] \\
\hline MT29-3 & white & $x$ & & - & 2.05 & -2.97 & [38] \\
\hline MT29-4 & white & $x$ & & - & 2.17 & -4.18 & [38] \\
\hline MT29-5 & white & $x$ & & - & 1.76 & -3.69 & [38] \\
\hline MT29-6 & white & $x$ & & - & 1.64 & -9.11 & [38] \\
\hline MT31-1 & white & $x$ & & 2.00 & 2.30 & -3.75 & [38] \\
\hline MT31-2 & white & $x$ & & 2.40 & 1.66 & -5.53 & [38] \\
\hline MT31-3 & white & $x$ & & - & 2.02 & -4.88 & [38] \\
\hline MT31-4 & white & $x$ & & - & 2.23 & -5.77 & [38] \\
\hline MT35-1 & white & $x$ & + & 3.20 & 1.99 & -2.73 & [38] \\
\hline MT35-2 & white & $x$ & & 2.00 & 1.91 & -2.96 & [38] \\
\hline MT35-3 & white & $x$ & & - & 1.12 & -2.49 & [38] \\
\hline MT35-4 & white & $x$ & & - & 2.00 & -2.70 & [38] \\
\hline MT39-1 & white & $x$ & & 2.10 & 2.54 & -2.39 & [38] \\
\hline MT39-2 & white & $x$ & & 2.00 & 2.39 & -1.78 & [38] \\
\hline MT39-3 & white veined & $x$ & & 3.50 & -1.05 & -2.60 & [38] \\
\hline MT39-4 & white & $x$ & & 4.40 & 2.05 & -2.87 & [38] \\
\hline MT39-5 & white & $x$ & & - & 2.03 & -2.46 & [38] \\
\hline MT39-6 & white & $x$ & & - & 2.22 & -2.46 & [38] \\
\hline MT43-1 & grey & $x$ & & 2.10 & 0.96 & -2.93 & [38] \\
\hline MT43-2 & white & $x$ & & 4.00 & 1.48 & -3.78 & [38] \\
\hline MT43-3 & white/yellowish & $x$ & & 2.00 & 1.30 & -10.23 & [38] \\
\hline MT43-4 & grey & $x$ & & 2.75 & 0.87 & -5.10 & [38] \\
\hline MT43-5 & grey & $x$ & & - & 0.57 & -4.07 & [38] \\
\hline
\end{tabular}


Table A1. Cont.

\begin{tabular}{|c|c|c|c|c|c|c|c|}
\hline Sample & Colour & $\mathrm{CC}$ & Dol & MGS & $\begin{array}{c}\delta^{13} \mathrm{C} \\
\text { (PDB) }\end{array}$ & $\begin{array}{c}\delta^{18} \mathrm{O} \\
\text { (PDB) }\end{array}$ & Lit \\
\hline \multicolumn{8}{|c|}{ Marmar Tepe } \\
\hline MT43-6 & grey & $\mathrm{x}$ & & - & 0.56 & -2.95 & [38] \\
\hline MT49-1 & grey & $x$ & & 2.90 & 1.63 & -3.46 & [38] \\
\hline MT49-2 & white & $x$ & & 2.00 & 0.51 & -2.26 & [38] \\
\hline MT49-3 & white & $x$ & & 3.20 & 1.40 & -2.67 & [38] \\
\hline MT49-4 & grey & $x$ & & 3.30 & 0.71 & -3.63 & [38] \\
\hline MT49-5 & grey & $x$ & & - & 0.70 & -3.44 & [38] \\
\hline MT49-6 & white veined & $x$ & & - & 1.44 & -4.02 & [38] \\
\hline MT52-1 & white & $x$ & & 2.50 & 1.90 & -3.14 & [38] \\
\hline MT52-2 & white & $x$ & & 2.40 & 1.51 & -2.98 & [38] \\
\hline MT52-3 & white & $x$ & & - & 2.05 & -3.23 & [38] \\
\hline MT52-4 & white & $x$ & & - & 0.59 & -2.83 & [38] \\
\hline MT52-5 & grey & $x$ & & - & 0.42 & -3.21 & [38] \\
\hline MT53-1 & white & $x$ & & 2.50 & 1.41 & -3.60 & [38] \\
\hline MT53-2 & white & $x$ & & 2.00 & 1.23 & -4.56 & [38] \\
\hline MT53-3 & white/yellowish & $x$ & & 2.90 & 1.61 & -3.70 & [38] \\
\hline MT53-4 & white & $x$ & & 2.90 & 1.42 & -4.12 & [38] \\
\hline MT58-1 & white & $x$ & & 3.20 & 1.56 & -4.17 & [38] \\
\hline MT58-2 & white & $x$ & & 3.60 & 1.05 & -3.70 & [38] \\
\hline MT58-3 & white & $x$ & & - & 1.49 & -3.40 & [38] \\
\hline MT58-4 & white & $x$ & & - & 1.42 & -3.44 & [38] \\
\hline MT58-5 & white & $x$ & & - & 1.68 & -4.83 & [38] \\
\hline MT58-6 & white & $x$ & & - & 0.64 & -2.77 & [38] \\
\hline MT60-1 & grey & $x$ & & 2.20 & 0.67 & -2.99 & [38] \\
\hline MT60-2 & white & $x$ & & 2.00 & 1.68 & -5.05 & [38] \\
\hline MT60-3 & white & $x$ & & - & 2.20 & -2.14 & [38] \\
\hline MT60-4 & white & $x$ & & - & 1.62 & -3.36 & [38] \\
\hline MT60-5 & white & $x$ & & - & 1.34 & -5.08 & [38] \\
\hline MT62-1 & white & $x$ & & 3.40 & 1.44 & -9.15 & [38] \\
\hline MT62-2 & grey & $x$ & & 2.00 & 1.53 & -2.65 & [38] \\
\hline MT62-3 & grey & $x$ & & - & 1.66 & -2.47 & [38] \\
\hline MT62-4 & white & $x$ & & - & 1.58 & -2.94 & [38] \\
\hline MT62-5 & white & $x$ & & - & 1.72 & -2.99 & [38] \\
\hline MT62-6 & white & $x$ & & - & 1.68 & -6.15 & [38] \\
\hline MT68-1 & grey & $x$ & & 4.50 & 1.51 & -2.16 & [38] \\
\hline MT68-2 & dark grey & $x$ & & 2.40 & 0.09 & -2.86 & [38] \\
\hline MT68-3 & white & $x$ & & 2.70 & 1.17 & -2.37 & [38] \\
\hline MT68-4 & white & $x$ & & 3.00 & 0.68 & -2.35 & [38] \\
\hline MT68-5 & white & $x$ & & - & 2.37 & -2.16 & [38] \\
\hline MT68-6 & white & $x$ & & - & 1.03 & -3.16 & [38] \\
\hline MT70-1 & white & $x$ & & 2.30 & 1.95 & -5.29 & [38] \\
\hline MT70-2 & white & $x$ & & 2.20 & 2.22 & -4.86 & [38] \\
\hline MT70-3 & white & $x$ & & - & 1.47 & -4.47 & [38] \\
\hline MT70-4 & white & $x$ & & - & 1.70 & -3.17 & [38] \\
\hline MT70-5 & white/brownish & $x$ & & - & 0.80 & -8.57 & [38] \\
\hline \multicolumn{8}{|l|}{ Thiounta } \\
\hline TH1-1 & white & $x$ & & 3.60 & 2.13 & -2.92 & [38] \\
\hline TH1-2 & white & $x$ & & 3.20 & 2.16 & -3.26 & [38] \\
\hline TH1-3 & white & $x$ & & 3.10 & 1.90 & -3.60 & [38] \\
\hline TH1-4 & white & $x$ & & 3.70 & 1.94 & -3.06 & [38] \\
\hline TH1-5 & white & $x$ & & - & 2.38 & -2.85 & [38] \\
\hline TH1-6 & white & $x$ & & - & 1.97 & -2.90 & [38] \\
\hline TH2-1 & white & $x$ & & 3.20 & 2.33 & -3.63 & [38] \\
\hline TH2-2 & white & $x$ & + & 3.00 & 2.56 & -3.04 & [38] \\
\hline TH2-3 & white & $x$ & & - & 2.41 & -3.30 & [38] \\
\hline TH2-4 & white & $x$ & & - & 2.07 & -3.68 & [38] \\
\hline TH3-1 & grey & $x$ & + & 3.60 & -0.72 & -2.60 & [38] \\
\hline TH3-2 & grey & $x$ & & 3.60 & -1.61 & -2.86 & [38] \\
\hline TH3-3 & grey & $x$ & & 2.60 & -0.89 & -2.52 & [38] \\
\hline TH3-4 & white & $x$ & & - & 2.45 & -4.01 & [38] \\
\hline TH3-5 & white & $x$ & & - & 1.34 & -8.06 & [38] \\
\hline TH3-6 & white & $x$ & & - & 1.18 & -10.65 & [38] \\
\hline TH3-7 & white & $x$ & & - & 2.18 & -2.88 & [38] \\
\hline TH3-8 & white & $x$ & & - & 1.83 & -3.44 & [38] \\
\hline te2 & 177 & $x$ & + & 2.90 & 0.88 & -3.38 & [35] \\
\hline te3 & 221 & $x$ & & 3.35 & 1.86 & -3.65 & [35] \\
\hline te4 & 216 & $x$ & \pm & 2.73 & 1.80 & -6.74 & [35] \\
\hline te5 & 224 & $x$ & & 3.25 & 1.78 & -5.89 & [35] \\
\hline te6 & 211 & $x$ & & 4.30 & 0.58 & -3.96 & [35] \\
\hline
\end{tabular}


Table A1. Cont.

\begin{tabular}{|c|c|c|c|c|c|c|c|}
\hline Sample & Colour & $\mathrm{CC}$ & Dol & MGS & $\begin{array}{c}\delta^{13} \mathrm{C} \\
\text { (PDB) }\end{array}$ & $\begin{array}{c}\delta^{18} \mathrm{O} \\
\text { (PDB) }\end{array}$ & Lit \\
\hline \multicolumn{8}{|l|}{ Thiounta } \\
\hline te7 & 215 & $x$ & \pm & 2.25 & 1.67 & -4.33 & [35] \\
\hline te8 & 211 & $x$ & & 3.50 & 1.84 & -3.55 & [35] \\
\hline te9 & 204 & $x$ & \pm & 2.80 & 0.85 & -2.99 & [35] \\
\hline te10 & 205 & $x$ & & 4.25 & 1.41 & -4.28 & [35] \\
\hline $\mathrm{t} 1$ & 174 & $x$ & \pm & 3.00 & 1.80 & -2.90 & [35] \\
\hline t2 & 208 & $x$ & & 2.70 & 2.23 & -4.46 & [35] \\
\hline t3 & 212 & $x$ & & 3.50 & 1.61 & -4.84 & [35] \\
\hline $\mathrm{t} 4$ & 197 & $x$ & & 3.00 & 1.60 & -3.43 & [35] \\
\hline t5 & 178 & $x$ & \pm & 1.85 & 1.80 & -2.86 & [35] \\
\hline t6 & 210 & $x$ & & 3.90 & 2.00 & -3.32 & [35] \\
\hline t7 & 195 & $x$ & \pm & 2.90 & 1.80 & -3.26 & [35] \\
\hline t8 & 204 & $x$ & \pm & 0.80 & 1.43 & -3.54 & [35] \\
\hline $\operatorname{tm} 1$ & 226 & $x$ & \pm & 2.80 & 1.74 & -7.37 & [35] \\
\hline tm2 & 223 & $x$ & & 5.00 & 1.57 & -5.53 & [35] \\
\hline $\operatorname{tm} 3$ & 217 & $x$ & \pm & 3.32 & 1.76 & -5.05 & [35] \\
\hline tm6 & 219 & $x$ & & 2.97 & 1.22 & -9.96 & [35] \\
\hline tm7 & 183 & $x$ & \pm & 2.60 & 2.02 & -3.00 & [35] \\
\hline $\operatorname{tm} 8$ & 221 & $x$ & \pm & 3.32 & 1.70 & -5.81 & [35] \\
\hline $\operatorname{tm} 9$ & 212 & $x$ & & 3.50 & 0.81 & -13.81 & [35] \\
\hline $\mathrm{T} 1$ & 213 & $x$ & & 3.40 & 1.98 & -3.05 & [35] \\
\hline T2 & 220 & $x$ & & 3.00 & 1.95 & -3.32 & [35] \\
\hline T4 & 227 & $x$ & & 3.50 & 1.81 & -3.52 & [35] \\
\hline T5 & 218 & $x$ & & 2.50 & 2.02 & -3.13 & [35] \\
\hline T6 & 237 & $x$ & & 3.40 & 2.01 & -3.54 & [35] \\
\hline T7 & 212 & $x$ & & 2.50 & 2.01 & -3.48 & [35] \\
\hline T8 & 226 & $x$ & & 3.30 & 1.75 & -3.54 & [35] \\
\hline T9 & 235 & $x$ & \pm & 2.20 & 2.12 & -3.72 & [35] \\
\hline T10 & 234 & $x$ & & 2.10 & 2.05 & -3.51 & [35] \\
\hline T11 & 231 & $x$ & & 2.50 & 2.04 & -3.54 & [35] \\
\hline T12 & 240 & $x$ & & 2.40 & 2.10 & -3.46 & [35] \\
\hline T13 & 228 & $x$ & & 2.40 & 1.66 & -3.65 & [35] \\
\hline T14c & 211 & $x$ & \pm & 2.50 & 2.03 & -3.08 & [35] \\
\hline T15 & 224 & $x$ & & 2.50 & 1.90 & -3.20 & [35] \\
\hline T16 & 219 & $x$ & & 2.50 & 2.00 & -3.19 & [35] \\
\hline T17 & 223 & $x$ & & 2.60 & 2.11 & -3.12 & [35] \\
\hline T18 & 211 & $x$ & & 3.20 & 1.99 & -3.14 & [35] \\
\hline T19 & 207 & $x$ & \pm & 2.70 & 1.72 & -3.57 & [35] \\
\hline T20 & 223 & $x$ & & 3.00 & 2.11 & -3.19 & [35] \\
\hline T22 & 212 & $x$ & & 2.40 & 1.53 & -3.16 & [35] \\
\hline \multicolumn{8}{|c|}{ Gölemezli } \\
\hline Gm1-1 & white & $x$ & & 5.20 & 2.83 & -3.84 & [38] \\
\hline Gm1-2 & white & $x$ & & 4.30 & 2.72 & -5.79 & [38] \\
\hline Gm1-3 & white & $x$ & & 4.20 & 2.48 & -4.16 & [38] \\
\hline Gm1-4 & white & $x$ & & 4.80 & 2.98 & -4.17 & [38] \\
\hline Gm1-5 & white & $x$ & & - & 2.62 & -3.89 & [38] \\
\hline Gm1-6 & white & $x$ & & - & 0.20 & -2.78 & [38] \\
\hline Gm2-1 & white & $x$ & & 3.20 & 2.36 & -3.03 & [38] \\
\hline Gm2-2 & grey & $x$ & \pm & 3.40 & 1.85 & -3.63 & [38] \\
\hline Gm2-3 & white & $x$ & & - & 2.36 & -3.84 & [38] \\
\hline Gm2-4 & white & $x$ & & - & 1.88 & -9.62 & [38] \\
\hline Gm2-5 & white & $x$ & & - & 2.63 & -3.27 & [38] \\
\hline \multicolumn{8}{|l|}{ Denizli-1 } \\
\hline D1-1 & white & $x$ & & 2.20 & 2.53 & -2.74 & [38] \\
\hline D1-2 & white & $x$ & & - & 2.44 & -1.85 & [38] \\
\hline D1-3 & white & $x$ & & - & 2.22 & -2.35 & [38] \\
\hline D2-1 & white & $x$ & & 2.00 & 3.24 & -2.90 & [38] \\
\hline D2-2 & white & $x$ & \pm & 2.60 & 2.68 & -2.38 & [38] \\
\hline D2-3 & white & $x$ & & - & 2.47 & -2.63 & [38] \\
\hline D2-4 & white & $x$ & & - & 2.70 & -2.33 & [38] \\
\hline D3-1 & white & $x$ & & 2.40 & 2.61 & -2.78 & [38] \\
\hline D3-2 & white & $x$ & & 1.80 & 2.67 & -2.55 & [38] \\
\hline D3-3 & white & $x$ & & 1.50 & 2.98 & -2.23 & [38] \\
\hline D3-4 & white & $x$ & & - & 2.71 & -2.92 & [38] \\
\hline D3-5 & white & $x$ & & - & 1.68 & -4.71 & [38] \\
\hline D3-6 & white & $x$ & & - & 3.00 & -2.61 & [38] \\
\hline D3-7 & white/reddish & $x$ & & - & 2.64 & -4.08 & [38] \\
\hline D3bis-1 & white & $x$ & & 1.50 & 2.08 & -2.20 & [38] \\
\hline D3bis-2 & white & $x$ & & 1.40 & 2.89 & -2.00 & [38] \\
\hline D3bis-3 & white & $x$ & & 4.00 & 2.56 & -2.43 & [38] \\
\hline
\end{tabular}


Table A1. Cont.

\begin{tabular}{|c|c|c|c|c|c|c|c|}
\hline Sample & Colour & $\mathrm{CC}$ & Dol & MGS & $\begin{array}{c}\delta^{13} \mathrm{C} \\
\text { (PDB) }\end{array}$ & $\begin{array}{c}\delta^{18} \mathrm{O} \\
(\mathrm{PDB})\end{array}$ & Lit \\
\hline \multicolumn{8}{|l|}{ Denizli-1 } \\
\hline D3bis-4 & white & $x$ & & 1.20 & 2.96 & -1.95 & [38] \\
\hline D3bis-5 & white & $x$ & & - & 2.67 & -2.40 & [38] \\
\hline D3bis-6 & white & $x$ & & - & 2.75 & -2.86 & [38] \\
\hline D3bis-7 & white & $x$ & & - & 2.28 & -2.26 & [38] \\
\hline D4-1 & white & $x$ & & 1.80 & 2.64 & -2.46 & [38] \\
\hline D4-2 & white & $x$ & & - & 2.46 & -2.86 & [38] \\
\hline D4-3 & white & $x$ & & - & 2.62 & -2.60 & [38] \\
\hline DEN1 & 186 & & & 0.90 & 1.89 & -2.49 & [35] \\
\hline DEN4 & 207 & & & 1.90 & 1.64 & -2.01 & [35] \\
\hline \multicolumn{8}{|l|}{ Denizli-2 } \\
\hline D5-1 & white & $x$ & & 0.96 & -0.08 & -9.46 & [38] \\
\hline D5-2 & white & $x$ & & 0.85 & -0.04 & -9.25 & [38] \\
\hline D5-3 & white & $x$ & & - & -0.13 & -9.35 & [38] \\
\hline D5-4 & white & $x$ & \pm & - & 0.03 & -9.59 & [38] \\
\hline DA1 & 203 & $x$ & \pm & 1.80 & 0.58 & -8.10 & [35] \\
\hline DA2 & 174 & $x$ & \pm & 1.90 & 2.24 & -7.40 & [35] \\
\hline DA4 & 158 & $x$ & \pm & 1.90 & 0.19 & -7.63 & [35] \\
\hline DA5 & 194 & $x$ & \pm & 1.50 & -0.16 & -8.05 & [35] \\
\hline DA7 & 165 & $x$ & \pm & 1.80 & -0.55 & -7.58 & [35] \\
\hline DA8 & 135 & $x$ & \pm & 1.60 & 0.29 & -7.13 & [35] \\
\hline DB1 & 227 & $x$ & \pm & 2.10 & 1.08 & -6.73 & [35] \\
\hline DB2 & 200 & $x$ & & 1.40 & 1.21 & -6.78 & [35] \\
\hline DB3 & 195 & $x$ & & 1.30 & 0.54 & -7.55 & [35] \\
\hline DB4 & 212 & $x$ & & 1.40 & 1.22 & -6.65 & [35] \\
\hline DB5 & 203 & $x$ & & 1.60 & 1.45 & -6.81 & [35] \\
\hline DB6 & 234 & $x$ & \pm & 1.90 & 2.00 & -6.96 & [35] \\
\hline DB7 & 203 & $x$ & & 1.10 & 2.98 & -6.06 & [35] \\
\hline DCD1 & 209 & $x$ & & 1.10 & 1.02 & -7.56 & [35] \\
\hline DCD2 & 218 & $x$ & & 1.60 & 1.16 & -7.41 & [35] \\
\hline DCD3 & 194 & $x$ & \pm & 1.10 & 0.96 & -7.52 & [35] \\
\hline DCD4 & 222 & $x$ & & 1.00 & 1.76 & -6.73 & [35] \\
\hline DCD5 & 201 & $x$ & & 1.00 & 2.47 & -6.30 & [35] \\
\hline DCD6 & 232 & $x$ & & 1.10 & 1.73 & -6.87 & [35] \\
\hline DCD7 & 227 & $x$ & & 1.00 & 1.37 & -6.62 & [35] \\
\hline DCD8 & 218 & $x$ & & 1.10 & 1.35 & -6.17 & [35] \\
\hline DCD9 & 227 & $x$ & & 1.10 & 1.23 & -6.79 & [35] \\
\hline DCD10 & 227 & $x$ & & 1.00 & -0.01 & -6.41 & [35] \\
\hline DCD11 & 231 & $x$ & & 1.10 & 0.83 & -7.21 & [35] \\
\hline DCD12 & 212 & $x$ & & 1.00 & -0.37 & -2.90 & [35] \\
\hline DCD13 & 200 & $x$ & & 1.10 & 0.48 & -7.41 & [35] \\
\hline DCD14 & 217 & $x$ & & 1.10 & 0.83 & -7.43 & [35] \\
\hline DCD15 & 226 & $x$ & & 1.30 & 0.73 & -7.58 & [35] \\
\hline BLO1 & 200 & $x$ & & 1.20 & 0.66 & -6.72 & [35] \\
\hline BLO2 & 208 & $x$ & & 1.00 & 0.50 & -7.63 & [35] \\
\hline BLO3 & 197 & $x$ & & 1.30 & 2.20 & -6.55 & [35] \\
\hline $\mathrm{BLO} 4$ & 200 & $x$ & & 2.40 & 0.32 & -7.63 & [35] \\
\hline DEN6 & 213 & $x$ & & 0.90 & 2.02 & -7.00 & [35] \\
\hline DEN9 & 213 & $x$ & & 1.30 & 2.00 & -6.89 & [35] \\
\hline DDR-25 & white & - & - & - & 1.19 & -7.83 & [36] \\
\hline DDR-26 & white & - & - & - & 0.32 & -8.70 & [36] \\
\hline DDR-27 & white & - & - & - & 2.54 & -8.35 & [36] \\
\hline DDR-28 & white & - & - & - & 1.49 & -7.10 & [36] \\
\hline DDR-32 & white & - & - & - & 2.51 & -8.39 & [36] \\
\hline DDR-33 & white & - & - & - & 2.25 & -7.27 & [36] \\
\hline DDR-15 & grey veined & - & - & - & -1.44 & -8.53 & [36] \\
\hline DDR-16 & grey veined & - & - & - & 1.03 & -7.30 & [36] \\
\hline DDR-19 & grey veined & - & - & - & -0.05 & -7.83 & [36] \\
\hline DDR-20 & grey veined & - & - & - & 0.10 & -7.82 & [36] \\
\hline DDR-21 & grey veined & - & - & - & -0.37 & -9.42 & [36] \\
\hline DDR-22 & grey veined & - & - & - & 2.03 & -7.00 & [36] \\
\hline DDR-35 & grey & - & - & - & 2.41 & -5.67 & [36] \\
\hline DDR-37 & grey & - & - & - & 2.66 & -13.26 & [36] \\
\hline DDR-39 & grey & - & - & - & 1.64 & -9.51 & [36] \\
\hline DDR-41 & grey & - & - & - & 3.14 & -6.39 & [36] \\
\hline DDR-42 & grey & - & - & - & 3.41 & -5.30 & [36] \\
\hline DDR-43 & grey & - & - & - & 2.73 & -6.52 & [36] \\
\hline \multicolumn{8}{|l|}{ Denizli-3 } \\
\hline DEN3 & 204 & $x$ & & 2.40 & -0.08 & -2.69 & [35] \\
\hline DEN5 & 199 & $x$ & & 2.40 & -0.18 & -2.77 & [35] \\
\hline
\end{tabular}


Table A1. Cont.

\begin{tabular}{|c|c|c|c|c|c|c|c|}
\hline Sample & Colour & $\mathrm{CC}$ & Dol & MGS & $\begin{array}{c}\delta^{13} C \\
\text { (PDB) }\end{array}$ & $\begin{array}{c}\mathcal{\delta}^{18} \mathrm{O} \\
\text { (PDB) }\end{array}$ & Lit \\
\hline \multicolumn{8}{|l|}{ Denizli-3 } \\
\hline DEN7 & 192 & $x$ & & 2.40 & -0.03 & -2.88 & [35] \\
\hline DEN12 & 200 & $x$ & & 3.50 & -0.37 & -2.90 & [35] \\
\hline DEN13 & 206 & $x$ & & 2.90 & -0.43 & -2.69 & [35] \\
\hline \multicolumn{8}{|l|}{ Yenişehir } \\
\hline $\mathrm{Y}-02$ & white & - & - & - & 1.20 & -9.57 & [37] \\
\hline Y-08 & white & - & - & - & -1.96 & -9.73 & [37] \\
\hline $\mathrm{Y}-10$ & white & - & - & - & 1.08 & -8.98 & [37] \\
\hline $\mathrm{Y}-14$ & white & - & - & - & 2.19 & -9.24 & [37] \\
\hline $\mathrm{Y}-16$ & white & - & - & - & 1,30 & -10.45 & [37] \\
\hline Y-07 & grey veined & - & - & - & 0.74 & -9.00 & [37] \\
\hline $\mathrm{Y}-11$ & grey veined & - & - & - & -1.21 & -9.68 & [37] \\
\hline $\mathrm{Y}-19$ & grey veined & - & - & - & 0.91 & -9.07 & [37] \\
\hline $\mathrm{Y}-25$ & grey veined & - & - & - & 2.69 & -9.19 & [37] \\
\hline $\mathrm{Y}-26$ & grey veined & - & - & - & 3.05 & -9.24 & [37] \\
\hline $\mathrm{Y}-09$ & grey & - & - & - & 2.59 & -8.56 & [37] \\
\hline Y-18 & grey & - & - & - & 2.54 & -9.2 & [37] \\
\hline $\mathrm{Y}-20$ & grey & - & - & - & 1.20 & -9.05 & [37] \\
\hline $\mathrm{Y}-21$ & grey & - & - & - & 1.81 & -9.1 & [37] \\
\hline Y-23 & grey & - & - & - & 2.41 & -9.22 & [37] \\
\hline
\end{tabular}

Table A2. Isotopic composition $\left(\delta^{13} \mathrm{C}, \delta^{18} \mathrm{O}\right)$ of the alabasters of the Hierapolis, Gölemezli and Tripolis quarries: data from archaeometric investigations on ancient quarries [43] (Table S1), [46] (Table 2), and geological studies on banded travertine deposits [22] (Table 4), [41] (Table 1), [42] (Table DR3), [44] (Table 6), [47] (Table A.1).

\begin{tabular}{|c|c|c|c|c|}
\hline Quarries & Sample & $\delta^{13} \mathrm{C}(\mathrm{PDB})$ & $\delta^{18} \mathrm{O}$ (PDB) & Lit \\
\hline \multicolumn{5}{|c|}{ Hierapolis: Çukurbağ-Öküzini } \\
\hline Çukurbağ & O6bis_2 & 5.88 & -16.66 & [40] \\
\hline Çukurbağ & O6bis_3 & 5.25 & -13.08 & {$[40]$} \\
\hline Çukurbağ & O6bis_1 & 4.91 & -15.48 & [40] \\
\hline Çukurbağ & O6bis_4 & 6.40 & -13.14 & [40] \\
\hline Çukurbağ & O6bis_5 & 5.70 & -12.36 & {$[40]$} \\
\hline Çukurbağ & O6_1 & 4.70 & -15.69 & [40] \\
\hline Çukurbağ & O6_2 & 5.19 & -12.55 & [40] \\
\hline Çukurbağ & O6_3 & 6.05 & -12.07 & {$[40]$} \\
\hline Çukurbağ & O6_4 & 5.32 & -10.87 & [40] \\
\hline Çukurbağ & O6_5 & 4.70 & -14.78 & [40] \\
\hline Çukurbağ & O10_1 & 5.77 & -11.37 & [40] \\
\hline Çukurbağ & O10_2 & 7.69 & -9.76 & [40] \\
\hline Çukurbağ & O10_4 & 5.49 & -15.52 & [40] \\
\hline Çukurbağ & O10_3 & 6.42 & -11.59 & [40] \\
\hline Çukurbağ & O10_5 & 6.50 & -11.80 & [40] \\
\hline Çukurbağ & Cuk1 & 5.79 & -14.10 & [42] \\
\hline Çukurbağ & PI-1 & 5.80 & -16.30 & [41] \\
\hline Çukurbağ & CB-11 & 5.20 & -15.80 & [22] \\
\hline Çukurbağ & CB-12a & 5.30 & -16.60 & [22] \\
\hline Çukurbağ & CB-13 & 5.10 & -11.10 & $\frac{12-1}{[22]}$ \\
\hline Öküzini & O11_5 & 7.28 & -9.36 & [40] \\
\hline Öküzini & O11_4 & 5.68 & -17.33 & [40] \\
\hline Öküzini & O11_3 & 6.73 & -11.43 & [40] \\
\hline Öküzini & O11_1 & 6.51 & -11.89 & [40] \\
\hline Öküzini & O11_2 & 5.72 & -17.46 & [40] \\
\hline Öküzini & PIV-1 & 5.70 & -14.30 & [41] \\
\hline Öküzini & PIV-2 & 5.60 & -15.00 & [41] \\
\hline \multicolumn{5}{|c|}{ Hierapolis: Yarıkkaya-Karakaya-Hanife } \\
\hline Yarıkkaya & O7bis_1 & 5.59 & -8.22 & [40] \\
\hline Yarıkkaya & O7bis_1a & 4.92 & -14.19 & [40] \\
\hline Yarkkkaya & O7bis_2 & 6.01 & -9.72 & {$[40]$} \\
\hline Yarıkkaya & O7bis_3 & 5.06 & -15.55 & [40] \\
\hline Yarıkkaya & O7bis_4 & 6.07 & -7.09 & [40] \\
\hline Yarkkkaya & O7_1 & 2.66 & -7.93 & {$[40]$} \\
\hline Yarıkkaya & O7_2 & 4.94 & -10.22 & [40] \\
\hline Yarıkkaya & O7_3 & 5.38 & -13.88 & {$[40]$} \\
\hline Yarıkkaya & O7_4 & 5.41 & -10.34 & [40] \\
\hline Yarıkkaya & O7_5 & 5.09 & -7.49 & [40] \\
\hline Yarıkkaya & PII-1 & 4.70 & -15.20 & [41] \\
\hline
\end{tabular}


Table A2. Cont.

\begin{tabular}{|c|c|c|c|c|}
\hline Quarries & Sample & $\delta^{13} \mathrm{C}(\mathrm{PDB})$ & $\delta^{18} \mathrm{O}(\mathrm{PDB})$ & Lit \\
\hline \multicolumn{5}{|c|}{ Hierapolis: Yarıkkaya-Karakaya-Hanife } \\
\hline Yarıkkaya & PII-3 & 4.80 & -14.40 & [41] \\
\hline Karakaya & Ak2 & 6.17 & -7.14 & [42] \\
\hline Karakaya & Ak3 & 5.27 & -11.00 & [42] \\
\hline Karakaya & Ak17 & 4.55 & -12.20 & [42] \\
\hline Karakaya & Ak19 & 4.97 & -11.85 & [42] \\
\hline Karakaya & Ak21 & 6.46 & -8.75 & [42] \\
\hline Karakaya & Ak22 & 7.11 & -9.23 & [42] \\
\hline Karakaya & Ak23 & 7.51 & -9.12 & [42] \\
\hline Karakaya & Ak25 & 4.71 & -10.40 & [42] \\
\hline Karakaya & Ak26 & 7.52 & -8.78 & [42] \\
\hline Hanife & O8_2 & 4.60 & -8.67 & [40] \\
\hline Hanife & O8_4 & 5.72 & -7.71 & [40] \\
\hline Hanife & O8_3 & 4.65 & -12.56 & [40] \\
\hline Hanife & O8_1 & 4.81 & -13.80 & [40] \\
\hline Hanife & O8_5 & 4.18 & -6.89 & [40] \\
\hline Hanife & O9_3 & 4.83 & -10.26 & [40] \\
\hline Hanife & O9_4 & 6.06 & -10.96 & [40] \\
\hline Hanife & O9_2 & 6.15 & -11.81 & [40] \\
\hline Hanife & O9_5 & 5.71 & -10.56 & [40] \\
\hline Hanife & O9_1 & 5.59 & -13.90 & [40] \\
\hline Hanife & PIII-1 & 4.90 & -14.50 & [41] \\
\hline Hanife & PIII-2 & 4.70 & -12.40 & [41] \\
\hline \multicolumn{5}{|c|}{ Hierapolis: Yokuşyol-Çallı } \\
\hline Yokuşyol & O3_2 & 4.94 & -12.34 & [40] \\
\hline Yokuşyol & O3_1 & 5.45 & -12.37 & [40] \\
\hline Yokuşyol & O1_7 & 4.83 & -13.92 & [40] \\
\hline Yokuşyol & O1_6V & 4.94 & -14.97 & [40] \\
\hline Yokuşyol & $\mathrm{O} 1 \_12 \mathrm{H}$ & 6.16 & -11.18 & [40] \\
\hline Yokuşyol & O1_3H & 6.57 & -10.35 & [40] \\
\hline Yokuşyol & O1_1 & 4.74 & -13.52 & [40] \\
\hline Yokuşyol & HB1 & 4.70 & -14.60 & [41] \\
\hline Yokuşyol & HCE & 5.10 & -11.30 & [41] \\
\hline Çallı & O5_1 & 6.38 & -13.89 & [40] \\
\hline Çallı & O5_2 & 6.38 & -7.75 & [40] \\
\hline Çallı & O5_3 & 7.16 & -8.52 & [40] \\
\hline Çallı & O5_4 & 6.58 & -8.28 & [40] \\
\hline \multicolumn{5}{|l|}{ Gölemezli } \\
\hline Gölemezli & GA1_5 & 3.71 & -15.29 & [40] \\
\hline Gölemezli & GA1_3 & 3.59 & -14.15 & [40] \\
\hline Gölemezli & GA1_2 & 3.85 & -14.77 & [40] \\
\hline Gölemezli & GA1_1 & 3.90 & -15.03 & [40] \\
\hline Gölemezli & GL-1 & 3.80 & -16.00 & [22] \\
\hline Gölemezli & GL-2 & 3.80 & -16.60 & [22] \\
\hline Gölemezli & GL-3 & 4.00 & -13.10 & [22] \\
\hline Gölemezli & GL-4 & 3.70 & -15.20 & [22] \\
\hline Gölemezli & GL-5 & -0.30 & -15.10 & [22] \\
\hline Gölemezli & GL-6 & 3.70 & -15.00 & [22] \\
\hline Gölemezli & GL-7 & 4.60 & -15.00 & [22] \\
\hline Gölemezli & TA1A & 3.92 & -14.81 & [47] \\
\hline Gölemezli & TA1B & 3.95 & -14.64 & [47] \\
\hline Gölemezli & TA1C & 4.09 & -14.48 & [47] \\
\hline Gölemezli & TA1D & 4.02 & -14.51 & [47] \\
\hline Gölemezli & TA1E & 3.89 & -14.76 & [47] \\
\hline Gölemezli & TA1F & 4.29 & -14.47 & [47] \\
\hline Gölemezli & TA23AA & 4.67 & -12.47 & [47] \\
\hline Gölemezli & TA23AB & 5.07 & -11.05 & [47] \\
\hline Gölemezli & TA23AC & 4.22 & -12.98 & [47] \\
\hline Gölemezli & TA23AD & 3.64 & -15.02 & [47] \\
\hline Gölemezli & TA23B & 4.15 & -11.42 & [47] \\
\hline Gölemezli & TA24A & 4.94 & -10.78 & [47] \\
\hline Gölemezli & TA24B & 3.65 & -15.14 & [47] \\
\hline Gölemezli & TA24C & 3.31 & -16.19 & [47] \\
\hline Gölemezli & TA24D & 3.72 & -12.70 & [47] \\
\hline Gölemezli & TA24E & 4.09 & -13.66 & [47] \\
\hline Gölemezli & TA26AA & 3.38 & -16.52 & [47] \\
\hline Gölemezli & TA26AB & 3.87 & -15.57 & [47] \\
\hline Gölemezli & TA26BA & 4.22 & -14.64 & [47] \\
\hline Gölemezli & TA26BB & 4.23 & -13.39 & [47] \\
\hline
\end{tabular}


Table A2. Cont.

\begin{tabular}{|c|c|c|c|c|}
\hline Quarries & Sample & $\delta^{13} C($ PDB $)$ & $\delta^{18} \mathrm{O}(\mathrm{PDB})$ & Lit \\
\hline \multicolumn{5}{|l|}{ Gölemezli } \\
\hline Gölemezli & TA26BC & 4.24 & -14.39 & [47] \\
\hline Gölemezli & TA26BD & 4.01 & -14.93 & [47] \\
\hline Gölemezli & TA27A & 4.40 & -14.13 & [47] \\
\hline Gölemezli & TA27B & 4.33 & -13.98 & [47] \\
\hline Gölemezli & TA27C & 4.07 & -14.28 & [47] \\
\hline Gölemezli & TA28AA & 3.52 & -13.54 & [47] \\
\hline Gölemezli & TA28AB & 4.21 & -14.88 & [47] \\
\hline Gölemezli & TA28AC & 3.78 & -14.98 & [47] \\
\hline Gölemezli & TA28AD & 4.39 & -14.63 & [47] \\
\hline Gölemezli & TA28AE & 4.14 & -14.92 & [47] \\
\hline Gölemezli & TA28BA & 3.57 & -15.45 & [47] \\
\hline Gölemezli & TA28BB & 3.83 & -15.34 & [47] \\
\hline Gölemezli & TA5A & 3.48 & -15.23 & [47] \\
\hline Gölemezli & TA5B & 3.42 & -15.72 & [47] \\
\hline Gölemezli & TA5C & 3.44 & -15.83 & [47] \\
\hline Gölemezli & TA5D & 3.66 & -15.24 & [47] \\
\hline Gölemezli & T2 & 3.93 & -14.44 & [47] \\
\hline Gölemezli & T46 & 4.81 & -13.15 & [47] \\
\hline Gölemezli & T47 & 4.11 & -14.95 & [47] \\
\hline Gölemezli & T9 & 4.12 & -15.00 & [47] \\
\hline Gölemezli & T14 & 3.93 & -15.13 & [47] \\
\hline Gölemezli & T11 & 4.12 & -14.58 & [47] \\
\hline Gölemezli & T10 & 4.37 & -14.65 & [47] \\
\hline Gölemezli & T18 & 4.08 & -15.32 & [47] \\
\hline Gölemezli & T21A & 3.95 & -14.95 & [47] \\
\hline Gölemezli & T21B & 3.97 & -14.76 & [47] \\
\hline Gölemezli & T21C & 3.11 & -8.11 & [47] \\
\hline Gölemezli & T21D & 3.61 & -14.42 & [47] \\
\hline Gölemezli & $\mathrm{T} 23 \mathrm{~A}$ & 4.53 & -12.94 & [47] \\
\hline Gölemezli & T23B & 3.56 & -6.88 & [47] \\
\hline Gölemezli & T23C & 4.40 & -13.96 & [47] \\
\hline Gölemezli & T51 & 4.34 & -14.14 & [47] \\
\hline Gölemezli & T7B & 4.05 & -15.28 & [47] \\
\hline Gölemezli & T4B & 3.59 & -15.71 & [47] \\
\hline \multicolumn{5}{|l|}{ Tripolis } \\
\hline Tripolis & TRPST-1 & 3.09 & -15.93 & [46] \\
\hline Tripolis & TRPST-4 & 3.35 & -14.75 & [46] \\
\hline Tripolis & TRPST-6 & 4.00 & -13.01 & [46] \\
\hline Tripolis & TRPST-11 & 2.99 & -15.01 & [46] \\
\hline Tripolis & TRPST-15 & 3.48 & -14.68 & [46] \\
\hline Tripolis & $\mathrm{Ka} 2$ & 2.92 & -13.60 & [42] \\
\hline Tripolis & $\mathrm{Ka} 4$ & 3.34 & -13.10 & [42] \\
\hline Tripolis & Ka7 & 3.19 & -13.20 & [42] \\
\hline Tripolis & TA17AA & 3.23 & -14.39 & [44] \\
\hline Tripolis & TA17AB & 3.31 & -14.14 & [44] \\
\hline Tripolis & TA17AC & 3.03 & -14.28 & [44] \\
\hline Tripolis & TA17AD & 3.33 & -14.14 & [44] \\
\hline Tripolis & TA17BA & 3.31 & -14.22 & [44] \\
\hline Tripolis & TA18A & 4.1 & -13.98 & [44] \\
\hline Tripolis & TA18B & 3.37 & -14.29 & [44] \\
\hline Tripolis & TA18C & 3.14 & -14.53 & [44] \\
\hline
\end{tabular}

\section{References}

1. D'Andria, F. Hierapolis di Frigia (Pamukkale); Ege Yayınları: Istanbul, Turkey, 2003.

2. Arthur, P. Hierapolis Bizantina e Turca (Pamukkale). Guida Archeologica; Ege Yayınları: Istanbul, Turkey, 2006.

3. Hierapolis di Frigia I. Le attività Delle Campagne di Scavo e Restauro 2000-2003; D'Andria, F., Caggia, M.P., Eds.; Ege Yayınları: Istanbul, Turkey, 2007.

4. Ismaelli, T. Hierapolis di Frigia III. Architettura Dorica a Hierapolis di Frigia; Ege Yayınları: Istanbul, Turkey, 2009.

5. Travaglini, A.; Camilleri, V.G. Hierapolis di Frigia IV. Le Monete, Campagne di scavo 1957-2004; Ege Yayınları: Istanbul, Turkey, 2010.

6. Hierapolis di Frigia V. Le Attività delle Campagne di scavo e Restauro 2004-2006; D'Andria, F., Caggia, M.P., Ismaelli, T., Eds.; Ege Yayınları: Istanbul, Turkey, 2012.

7. Romeo, I.; Panariti, D.; Ungaro, R. Hierapolis di Frigia VI. La Tomba Bella. Un Heroon Giulio-Claudio e il suo Sarcofago; Ege Yayınları: Istanbul, Turkey, 2014. 
8. Nuovo Atlante di Hierapolis di Frigia. Cartografia Archeologica Della Città e delle Necropoli; Scardozzi, G., Ed.; Ege Yayınlar1: Istanbul, Turkey, 2015.

9. Hierapolis di Frigia VIII. Le Attività Delle Campagne di Scavo e Restauro 2007-2011; D'Andria, F., Caggia, M.P., Ismaelli, T., Eds.; Ege Yayınları: Istanbul, Turkey, 2016.

10. Ismaelli, T. Hierapolis di Frigia X. Il Tempio A nel Santuario di Apollo. Architettura, decorazione e contesto; Ege Yayınları: Istanbul, Turkey, 2017.

11. Ritti, T. Hierapolis di Frigia IX. Storia e Istituzioni di Hierapolis; Ege Yayınları: Istanbul, Turkey, 2017.

12. Campagna, L. Hierapolis di Frigia XI. Il Ninfeo dei Tritoni; Ege Yayınları: Istanbul, Turkey, 2018.

13. Şimşek, C. Laodikeia (Laodikeia ad Lycum); Ege Yayınları: Istanbul, Turkey, 2007.

14. Duman, B. Son arkeolojik araştirmalar ve yeni bulgular işiğinda Tripolis ad Maeandrum. Cedrus 2013, 1, 179-200. [CrossRef]

15. Şimşek, C. Laodikeia (Laodikeia ad Lycum). Laodikeia Çalişmalari 2; Ege Yayınları: Istanbul, Turkey, 2013.

16. Duman, B.; Baysal, H. Tripolis 2. Sezon kazi ve restorasyon raporu: 2013. Kazı Sonuçları Toplantısı 2015, 36, 633-665.

17. Duman, B. Tripolis'te Gerçekleştirilen Arkeolojik Araştırmaların Özeti (2012-2015). Geçmişten Günümüze Denizli, Özel Sayı 2016, 47, 78-87.

18. Duman, B.; Baysal, H. Tripolis ad Maeandrum 2014 Yılı Kazı, Onarım ve Koruma Çalışmaları. Kazı Sonuçları Toplantısı 2016, 37, 563-584.

19. Şimşek, C. Marble in ancient architecture of Laodikeia on the Lykos: New evidence. In Ancient Quarries and Building Sites in Asia Minor. Research on Hierapolis in Phrygia and Other Cities in South-Western Anatolia: Archaeology, Archaeometry, Conservation; Ismaelli, T., Scardozzi, G., Eds.; Edipuglia: Bari, Italy, 2016; pp. 701-710.

20. Özkul, M.; Varol, B.; Alçiçek, M.C. Depositional environments and petrography of the Denizli travertines. Bull. Mineral Res. Explor. 2002, 125, 13-29.

21. Alçiçek, H.; Varol, B.; Özkul, M. Sedimentary facies, depositional environments and palaeogeographic evolution of the Neogene Denizli Basin, SW Anatolia, Turkey. Sedimen. Geol. 2007, 202, 596-637. [CrossRef]

22. Özkul, M.; Kele, S.; Gökgöz, A.; Shen, C.C.; Jones, B.; Baykara, M.O.; Fòrizs, I.; Németh, T.; Chang, Y.W.; Alçiçek, M.C. Comparison of the Quaternary travertine sites in the Denizli extensional basin based on their depositional and geochemical data. Sedimen. Geol. 2013, 294, 179-204. [CrossRef]

23. Kumsar, H.; Aydan, Ö.; Şimşek, C.; D'Andria, F. Historical earthquakes that damaged Hierapolis and Laodikeia antique cities and their implications for earthquake potential of Denizli basin in western Turkey. Bull. Eng. Geol. Environ. 2015, 75, 519-536. [CrossRef]

24. Barone, P.M. General setting of the geology and tectonics of the Denizli basin. In Ancient Quarries and Building Sites in Asia Minor. Research on Hierapolis in Phrygia and Other Cities in South-Western Anatolia: Archaeology, Archaeometry, Conservation; Ismaelli, T., Scardozzi, G., Eds.; Edipuglia: Bari, Italy, 2016; pp. 63-77.

25. Ancient Quarries and Building Sites in Asia Minor. Research on Hierapolis in Phrygia and Other Cities in South-Western Anatolia: Archaeology, Archaeometry, Conservation; Ismaelli, T., Scardozzi, G., Eds.; Edipuglia: Bari, Italy, 2016.

26. Ditaranto, I. Ancient marble quarries in the territory of Hierapolis. In Ancient Quarries and Building Sites in Asia Minor. Research on Hierapolis in Phrygia and Other Cities in South-Western Anatolia: Archaeology, Archaeometry, Conservation; Ismaelli, T., Scardozzi, G., Eds.; Edipuglia: Bari, Italy, 2016; pp. 87-100.

27. Scardozzi, G. The alabaster quarries of Hierapolis. In Ancient Quarries and Building Sites in Asia Minor. Research on Hierapolis in Phrygia and Other Cities in South-Western Anatolia: Archaeology, Archaeometry, Conservation; Ismaelli, T., Scardozzi, G., Eds.; Edipuglia: Bari, Italy, 2016; pp. 141-166.

28. Barone, P.M.; Scardozzi, G. Optical high-resolution satellite imagery for the study of the ancient quarries of Hierapolis. In Ancient Quarries and Building Sites in Asia Minor. Research on Hierapolis in Phrygia and Other Cities in South-Western Anatolia: Archaeology, Archaeometry, Conservation; Ismaelli, T., Scardozzi, G., Eds.; Edipuglia: Bari, Italy, 2016; pp. 657-668.

29. Marabini, S. Geological and geomorphological setting of the area surrounding Hierapolis. In Ancient Quarries and Building Sites in Asia Minor. Research on Hierapolis in Phrygia and Other Cities in South-Western Anatolia: Archaeology, Archaeometry, Conservation; Ismaelli, T., Scardozzi, G., Eds.; Edipuglia: Bari, Italy, 2016; pp. 79-84. 
30. Ismaelli, T. Architecture and decoration in context: A cross analysis of the ancient building site in five steps. The case study of the Severan Temple A in the Sanctuary of Apollo. In Ancient Quarries and Building Sites in Asia Minor. Research on Hierapolis in Phrygia and Other Cities in South-Western Anatolia: Archaeology, Archaeometry, Conservation; Ismaelli, T., Scardozzi, G., Eds.; Edipuglia: Bari, Italy, 2016; pp. 339-364.

31. Maschek, D. The Marble Stoa at Hierapolis. Materials, labour force and building costs. In Ancient Quarries and Building Sites in Asia Minor. Research on Hierapolis in Phrygia and Other Cities in South-Western Anatolia: Archaeology, Archaeometry, Conservation; Ismaelli, T., Scardozzi, G., Eds.; Edipuglia: Bari, Italy, 2016; pp. 393-402.

32. Ismaelli, T.; Bozza, S. Ancient construction sites in Hierapolis: New data on strategies, materials and techniques. In Ancient Quarries and Building Sites in Asia Minor. Research on Hierapolis in Phrygia and Other Cities in South-Western Anatolia: Archaeology, Archaeometry, Conservation; Ismaelli, T., Scardozzi, G., Eds.; Edipuglia: Bari, Italy, 2016; pp. 437-458.

33. Leucci, G.; Ismaelli, T.; Scardozzi, G. Geophisical surveys at Hierapolis. New data on monuments and tectonic context. In Ancient Quarries and Building Sites in Asia Minor. Research on Hierapolis in Phrygia and Other Cities in South-Western Anatolia: Archaeology, Archaeometry, Conservation; Ismaelli, T., Scardozzi, G., Eds.; Edipuglia: Bari, Italy, 2016; pp. 635-656.

34. Attanasio, D. Ancient White Marbles: Analysis and Identification by Paramagnetic Resonance Spectroscopy; L'Erma di Bretschneider: Roma, Italy, 2003.

35. Attanasio, D.; Brilli, M.; Ogle, N. The Isotopic Signature of Classical Marbles; L'Erma di Bretschneider: Roma, Italy, 2006.

36. Koralay, T.; Kılınçarslan, S. Minero-petrographic and isotopic characterization of two antique marble quarries in the Denizli region (western Anatolia, Turkey). Period. Mineral. 2015, 84, 263-288.

37. Koralay, T. Archaeometric characterization of the recently discovered Yenişehir marble quarry in the Denizli region. In Ancient Quarries and Building Sites in Asia Minor. Research on Hierapolis in Phrygia and Other Cities in South-Western Anatolia: Archaeology, Archaeometry, Conservation; Ismaelli, T., Scardozzi, G., Eds.; Edipuglia: Bari, Italy, 2016; pp. 119-130.

38. Brilli, M.; Conte, A.M.; Giustini, F.; Lapuente Mercadal, M.P.; Melica, D.; Royo Plumed, H.; Scardozzi, G. Archaeometric characterization of white marble from the ancient quarries in the territory of Hierapolis and in the southern sector of the Denizli basin, with an appendix on the Aphrodisian marble. In Ancient Quarries and Building Sites in Asia Minor. Research on Hierapolis in Phrygia and Other Cities in South-Western Anatolia: Archaeology, Archaeometry, Conservation; Ismaelli, T., Scardozzi, G., Eds.; Edipuglia: Bari, Italy, 2016; pp. 101-118.

39. Quarta, G.; Brilli, M.; Giustini, F.; Lapuente Mercadal, M.P.; Melica, D.; Ismaelli, T.; Royo Plumed, H.; Scardozzi, G. Provenance of the marbles used in the monuments of Hierapolis through an archaeometric approach: Petrography, isotopes and cathodoluminescence. In Ancient Quarries and Building Sites in Asia Minor. Research on Hierapolis in Phrygia and Other Cities in South-Western Anatolia: Archaeology, Archaeometry, Conservation; Ismaelli, T., Scardozzi, G., Eds.; Edipuglia: Bari, Italy, 2016; pp. 183-230.

40. Brilli, M.; Giustini, F.; Barone, P.M.; Fayek, A.; Scardozzi, G. Characterizing the Alabastro listato or fiorito of Hierapolis in Phrygia: A simple method to identify its provenance using carbon stable isotopes. Archaeometry 2017. [CrossRef]

41. Uysal, I.T.; Feng, Y.; Zhao, J.; Altunel, E.; Weatherley, D.; Karabacak, V.; Cengiz, O.; Golding, S.D.; Lawrence, M.G.; Collerson, K.D. U-series dating and geochemical tracing of late Quaternary travertine in co-seismic fissures. Earth Planet. Sci. Lett. 2007, 257, 450-462. [CrossRef]

42. De Filippis, L.; Faccenna, C.; Billi, A.; Anzalone, E.; Brilli, M.; Özkul, M.; Soligo, M.; Tuccimei, P.; Villa, I.M. Growth of fissure ridge travertines from geothermal springs of Denizli Basin, western Turkey. Geol. Soc. Am. Bull. 2012, 124, 1629-1645. [CrossRef]

43. Brilli, M.; Giustini, F.; Scardozzi, G. Calcite alabaster artefacts from Hierapolis in Phrygia (Turkey): Provenance determination using carbon and oxygen stable isotopes. Geoarchaeology 2018. [CrossRef]

44. Brogi, A.; Alçiçek, M.C.; Yalçıner, C.C.; Capezzuoli, E.; Liotta, D.; Meccheri, M.; Rimondi, V.; Ruggieri, G.; Gandin, A.; Boschi, C.; et al. Hydrothermal fluids circulation and travertine deposition in an active tectonic setting: Insights from the Kamara geothermal area (western Anatolia, Turkey). Tectonophysics 2016, 680, 211-232. [CrossRef] 
45. Koralay, T.; Duman, B.; Deniz, K.; Kadioğlu, Y.K. The provenance of banded travertine from the Ancient City of Tripolis (Yenice/Buldan-Denizli) based on the minero-petrographic and geochemical characterization. In Landscape and History in the Lykos Valley: Laodikeia and Hierapolis in Phrygia; Şimşek, C., D'Andria, F., Eds.; Cambridge Scholars Publishing: Cambridge, UK, 2017; pp. 143-164.

46. Koralay, T.; Baykara, M.O.; Deniz, K.; Kadioğlu, Y.K.; Duman, B.; Shen, C.-C. Multi-isotope investigations for scientific characterisation and provenance implication of banded travertines from Tripolis antique city (Denizli-Turkey). Environ. Archaeol. 2018. [CrossRef]

47. Capezzuoli, E.; Ruggieri, G.; Rimondi, V.; Brogi, A.; Liotta, D.; Alçiçek, M.C.; Alçiçek, H.; Bülbül, A.; Gandin, A.; Meccheri, M.; et al. Calcite veining and feeding conduits in a hydrothermal system: Insights from a natural section across the Pleistocene Gölemezli travertine depositional system (western Anatolia, Turkey). Sediment. Geol. 2018, 364, 180-203. [CrossRef]

48. Scardozzi, G. General considerations on the ancient marble quarries in the territory of Hierapolis and in the southern sector of the Denizli basin: Between topography and archaeometry. In Ancient Quarries and Building Sites in Asia Minor. Research on Hierapolis in Phrygia and Other Cities in South-Western Anatolia: Archaeology, Archaeometry, Conservation; Ismaelli, T., Scardozzi, G., Eds.; Edipuglia: Bari, Italy, 2016; pp. 131-140.

49. Ahrens, S.; Brilli, M.; Caggia, M.P.; Cox, J.; Maniatis, Y.; Quarta, G.; Lapuente Mercadal, M.P.; Scardozzi, G.; Tambakopoulos, D.; Van Keuren, F. Marble sarcophagi from the St Philip Church of Hierapolis and the North-East Necropolis: Archaeometric characterization and marble provenance identification. In Ancient Quarries and Building Sites in Asia Minor. Research on Hierapolis in Phrygia and Other Cities in South-Western Anatolia: Archaeology, Archaeometry, Conservation; Ismaelli, T., Scardozzi, G., Eds.; Edipuglia: Bari, Italy, 2016; pp. 259-276.

50. Scardozzi, G. Marble supply strategies in the building sites of Hierapolis. In Ancient Quarries and Building Sites in Asia Minor. Research on Hierapolis in Phrygia and Other Cities in South-Western Anatolia: Archaeology, Archaeometry, Conservation; Ismaelli, T., Scardozzi, G., Eds.; Edipuglia: Bari, Italy, 2016; pp. 421-435.

51. Cantisani, E.; Scardozzi, G. The polychromatic breccia of Hierapolis: Quarries, use in construction sites, alteration phenomena. In Ancient Quarries and Building Sites in Asia Minor. Research on Hierapolis in Phrygia and Other Cities in South-Western Anatolia: Archaeology, Archaeometry, Conservation; Ismaelli, T., Scardozzi, G., Eds.; Edipuglia: Bari, Italy, 2016; pp. 167-180.

52. Bruno, M. Alabaster quarries near Hierapolis (Turkey). In Interdisciplinary Studies on Ancient Stone, Proceedings of the Sixth International Conference ASMOSIA, Venice, Italy, 15-18 June 2000; Lazzarini, L., Ed.; Bottega d'Erasmo: Padova, Italy, 2002; pp. 19-24.

53. Pensabene, P. I marmi Nella Roma Antica; Carocci: Roma, Italy, 2013.

54. Altunel, E.; Hancock, P.L. Active fissuring and faulting in Quaternary travertines at Pamukkale, western Turkey. In Neotectonics and Active Faulting; Stewart, I.S., Vita-Finzi, C., Owen, L.A., Eds.; Zeitschrift für Geomorphologie, Supplementary Issues, Volume 94; Gebruder Borntraeger: Berlin-Stuttgart, Germany, 1993; pp. 285-302.

55. Altunel, E.; Hancock, P.L. Morphological features and tectonic setting of Quaternary travertines at Pamukkale, western Turkey. Geol. J. 1993, 28, 335-346. [CrossRef]

56. Altunel, E.; Hancock, P.L. Structural attributes of travertine filled extensional fissures in the Pamukkale plateau, western Turkey. Int. Geol. Rev. 1996, 38, 768-777. [CrossRef]

57. Çakır, Z. Along-strike discontinuity of active normal faults and its influence on Quaternary travertine deposition: Examples from western Turkey. Turk. J. Earth Sci. 1999, 8, 67-80.

58. Hancock, P.L.; Altunel, E. Faulted archaeological relics at Hierapolis (Pamukkale), Turkey. J. Geodyn. 1997, 24, 21-36. [CrossRef]

59. Hancock, P.L.; Chalmers, R.M.L.; Altunel, E.; Çakır, Z. Travitonics: Using travertines in active fault studies. J. Struct. Geol. 1999, 21, 903-916. [CrossRef]

60. Hancock, P.L.; Chalmers, R.M.L.; Altunel, E.; Çakır, Z.; Becher-Hancock, A. Creation and destruction of travertine monumental stone by earthquake faulting at Hierapolis, Turkey. In The Archaeology of Geological Catastrophes; McGuire, W.G., Griffiths, D.R., Hancock, P.L., Stewart, I.S., Eds.; The Geological Society: London, UK, 2000; pp. 1-14.

61. Altunel, E.; Karabacak, V. Determination of horizontal extension from fissure-ridge travertines: A case study from the Denizli Basin, southwestern Turkey. Geodin. Acta 2005, 18, 335-342. [CrossRef] 
62. Uysal, I.T.; Feng, Y.; Zhao, J.; Işı1, V.; Nuriel, P.; Golding, S.D. Hydrothermal $\mathrm{CO}_{2}$ degassing in seismically active zones during the late Quaternary. Chem. Geol. 2009, 265, 442-454. [CrossRef]

63. Brogi, A.; Capezzuoli, E.; Alçiçek, M.C.; Gandin, A. Evolution of a fault-controlled fissure-ridge type travertine deposit in the western Anatolia extensional province: The Çukurbağ fissure-ridge (Pamukkale, Turkey). J. Geol. Soc. 2014, 171, 425-441. [CrossRef]

64. Mesci, B.L.; Tatar, O.; Piper, J.D.A.; Gürsoy, H.; Altunel, E.; Crowley, S. The efficacy of travertine as a palaeoenvironmental indicator: Palaeomagnetic study of neotectonic examples from Denizli, Turkey. Turk. J. Earth Sci. 2013, 22, 191-203.

65. Alçiçek, H.; Bülbül, A.; Alçiçek, M.C. Hydrogeochemistry of the thermal waters from the Yenice Geothermal Field (Denizli Basin, Southwestern Anatolia, Turkey). J. Volcanol. Geotherm. Res. 2016, 309, 118-138. [CrossRef]

66. Long, L.E. The Regional Marble Quarries. In The Aphrodisias Regional Survey; Aphrodisias, V., Ratté, C., De Staebler, P., Eds.; Verlag Philipp von Zabern: Darmstadt, Germany, 2012; pp. 165-201.

67. Attanasio, D.; Bruno, M.; Yavuz, A.B. On the provenance of some sculptural and decorative marbles used at Aphrodisias. Rendiconti dell'Accademia Nazionale dei Lincei, Classe Di Scienze Morali, Storiche e Filologiche 2014, 9, 105-151.

68. Russel, B. The Economics of the Roman Stone Trade; Oxford University Press: Oxford, UK, 2013.

(C) 2019 by the author. Licensee MDPI, Basel, Switzerland. This article is an open access article distributed under the terms and conditions of the Creative Commons Attribution (CC BY) license (http:/ / creativecommons.org/licenses/by/4.0/). 